\title{
Microglial Keratan Sulfate Epitope Elicits in Central Nervous Tissues of Transgenic Model Mice and Patients with Amyotrophic Lateral Sclerosis
}

Tahmina Foyez, ${ }^{*}$ Yoshiko Takeda-Uchimura, ${ }^{*}$ Shinsuke Ishigaki, ${ }^{\dagger}$ Narentuya, ${ }^{*}$ Zui Zhang, ${ }^{*}$ Gen Sobue, ${ }^{\dagger}$ Kenji Kadomatsu, ${ }^{*}$ and Kenji Uchimura*

From the Departments of Biochemistry* and Neurology, ${ }^{\dagger}$ Nagoya University Graduate School of Medicine, Nagoya, Japan

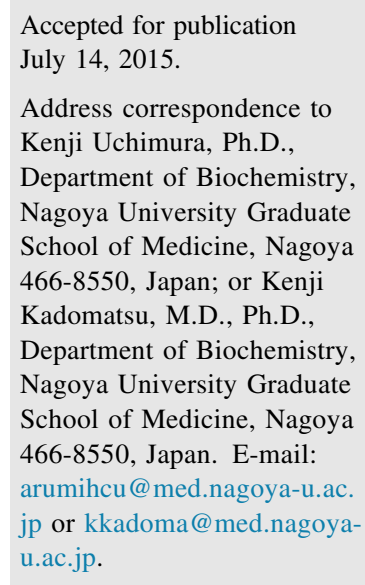

\begin{abstract}
The functional role of 5D4 antibody-reactive keratan sulfate (KS) in the pathogenesis of neurodegenerative diseases is unknown. We therefore studied the expression of 5D4-reactive KS in amyotrophic lateral sclerosis (ALS), a motor neuron-degenerative disease, with the use of SOD1 ${ }^{\text {G93A }}$ ALS model mice and patients with ALS. Histochemical and immunoelectron microscopic characterizations showed that the 5D4-reactive KS is expressed in Mac2/galectin-3-positive activated or proliferating microglia of SOD $1^{\text {G93A }}$ ALS model mice at disease end stage and that the KS is an 0 -linked glycan modified with sialic acid and fucose, which was thus far shown to exist in cartilage. Intriguingly, microglial KS was detected in the spinal cord and brainstem but not in the cerebral cortex of SOD1 ${ }^{\text {G93A }}$ mice. We found that KSGal6ST, a galactose-6-sulfotransferase, is required for biosynthesis of the microglial 5D4-reactive KS by generating S0D $1^{\mathrm{G} 93 \mathrm{~A}} / \mathrm{KSGal6ST}^{-/-}$mice. The requirement of GlcNAc6ST1 for this synthesis was corroborated by analyzing SOD $1^{\mathrm{G93A}} / \mathrm{GlcNAC6ST}^{-/-}$mice. These results indicate that both galactose-6- and $N$ acteylglucosamine-6-sulfated KS elicited in the spinal cord and brainstem are associated with the degeneration of spinal and bulbar lower motor neurons in ALS pathology and may play a role in disease progression via microglial activation and proliferation. (Am J Pathol 2015, 185: 3053-3065; http://dx.doi.org/10.1016/j.ajpath.2015.07.016)
\end{abstract}

Glycan structures often show characteristic differences between a normal state and disease. Knowledge of diseasespecific glycan structures can help to understand the mechanisms underlying disease progression and to develop new diagnostic and therapeutic approaches. Keratan sulfate (KS) is an extracellular polysaccharide classified as a member of the glycosaminoglycans. It was originally isolated from the cornea. ${ }^{1} \mathrm{KS}$ is also found in skeletal and nervous tissues. ${ }^{2,3}$ In terms of the composition of KS proteoglycans, one or more KS chains are covalently attached to a core protein through the elongation of $\mathrm{N}$-linked, $\mathrm{O}-\mathrm{N}$-acetylgalactosamine (GalNAc)-linked or $O$-mannose-linked oligosaccharides. ${ }^{4,5}$ $\mathrm{KS}$ is composed of repeating disaccharides of galactose (Gal) and $N$-acetylglucosamine (GlcNAc), with sulfate groups at their C-6 positions. ${ }^{2,6}$ The capping structures at their nonreducing termini vary and include modifications with $\alpha 3$ - or $\alpha 6$-linked sialic acid, $\alpha 3$-linked Gal, or $\beta 3$-linked sulfated GalNAc. ${ }^{7,8}$ Golgi-resident enzymes catalyze sulfation modifications and elongation of the $\mathrm{KS}$ disaccharides, producing diversity in the chains' structure. The C-6 sulfation modifications in $\mathrm{KS}$ synthesis are dictated by the Gal/GlcNAc/GalNAc sulfotransferases. 9 Among those, GlcNAc6ST1, GlcNAc6ST3, GlcNAc6ST5, and KS galactose-6-sulfotransferase (KSGal6ST) (encoded by the Chst2, Chst5, CHST6, and Chst1 genes, respectively) were reported to mediate $\mathrm{KS}$ sulfation in vivo. ${ }^{10-12}$

Several monoclonal antibodies against KS were used to evaluate KS expression. ${ }^{13-16}$ 5D4 recognizes KS oligosaccharide structures with absolute dependence on both Gal- and GlcNAc-6-sulfation modifications. ${ }^{11,12,17,18}$

Supported by the Ministry of Education, Science, Sports and Culture Scientific Research on Innovative Areas (K.K.), grants-in-aid 22790303 and 24590349 (K.U.), grants from the Takeda Science Foundation (K.U.), and the Kobayashi International Scholarship Foundation (K.U.).

Disclosures: None declared. 
However, additional glycosylation modifications of the 5D4-reactive KS glycan and the precise structure of the 5D4 epitope still remain to be determined. 5D4 was raised initially against human articular cartilage proteoglycans. ${ }^{13}$ In central nervous system tissues, the expression of the 5D4-reactive $\mathrm{KS}$ is induced in rodent models after injury. ${ }^{18,19}$ We have shown that treatment with keratanase II, a KS-degrading bacterial enzyme, or deficiency in the Chst 2 gene increased axonal sprouting and regeneration in injured nervous tissues. ${ }^{20,21}$ Expression of the 5D4 epitope was also found physiologically in the developing brain of rat and mouse. ${ }^{12,22,23}$ Expression of the 5D4 epitope in microglia is extensively induced with neurodegeneration in mouse models of cerebral amyloid angiopathy, ${ }^{24,25}$ familial Danish dementia, ${ }^{26}$ and light-induced retinal degeneration. ${ }^{27}$ However, the functional role of 5D4reactive $\mathrm{KS}$ in the pathogenesis of neurodegenerative disease is unknown.

Amyotrophic lateral sclerosis (ALS) is a devastating neurodegenerative disease that attacks spinal and bulbar motor neurons (lower motor neurons) in the spinal cord and brainstem and corticospinal and corticobulbar motor neurons (upper motor neurons) in the cerebral cortex, leading to progressive muscle weakness and complete paralysis within 1 to 5 years after disease onset. ${ }^{28}$ The mutation of expanded GGGGCC hexanucleotide repeat in the C9ORF72 gene is the most common cause of ALS. The repeat expansions are related to up to $40 \%$ of familial ALS and $10 \%$ of sporadic ALS in the United States and Europe. ${ }^{29}$ Mutations in the gene encoding copper-zinc superoxide dismutase (SODI) are found in $10 \%$ to $20 \%$ of familial ALS and up to $5 \%$ of sporadic ALS globally. ${ }^{30,31}$ The $\mathrm{SOD} 1^{\mathrm{G} 93 \mathrm{~A}}$ transgenic mouse is an ALS model mouse. ${ }^{32}$ This mouse develops an ALS-like phenotype that includes loss of motor neurons in the spinal cord by the disease end stage. ${ }^{32}$ It was reported that the lower and upper motor neurons degenerate independently of each other and that these degenerative processes are associated with intense inflammatory reactions in the spinal cord and brain. ${ }^{33}$ New methods to monitor the progression of degenerative changes in the lower and upper motor neurons will help our understanding of causative mechanisms underlying ALS and aid to develop therapeutic strategies. Recently, we have shown that the 5D4 epitope is induced in microglia in the spinal cord of $\mathrm{SOD} 1^{\mathrm{G} 93 \mathrm{~A}}$ mice with disease progression and that GlcNAc6ST1 is involved in 5D4-reactive KS synthesis. ${ }^{34}$ It was unclear whether the microglial 5D4-KS glycan is elicited in the brainstem and cerebral cortex of SOD $1^{\mathrm{G} 93 \mathrm{~A}}$ mice. The sulfotransferase responsible for Gal-6-sulfation within the $5 \mathrm{D} 4-\mathrm{KS}$ in microglia of SOD $1^{\mathrm{G} 93 \mathrm{~A}}$ mouse has remained unknown. Here, we report that the microglial 5D4-KS consists of sialyl-, fucosyl-, $O$-linked glycans, and that the 5D4-KS is expressed in the brainstem but not in the cerebral cortex of SOD $1^{\mathrm{G} 93 \mathrm{~A}}$ mice. We have also found that KSGal6ST is an enzyme required for Gal-6sulfation within the microglial 5D4-reactive $\mathrm{KS}$ in the spinal cord and brainstem of $\mathrm{SOD} 1^{\mathrm{G} 93 \mathrm{~A}}$ mice, with a corroborating correlation between the expression level of GlcNAc6ST1 and the 5D4 epitope.

\section{Materials and Methods}

Mice

C57BL/6J mice were purchased from SLC Inc. (Hamamatsu, Japan). ALS model B6.Cg-Tg(SOD1*G93A)1Gur/ $\mathrm{J}\left(\mathrm{SOD} 1^{\mathrm{G} 93 \mathrm{~A}}\right)$ mice $^{32}$ obtained from The Jackson Laboratory (Bar Harbor, ME) were provided by Dr. Akio Suzumura, Nagoya University, Japan. The generation of GlcNAc6ST1-deficient (GlcNAc6ST1 ${ }^{-/-}$) or KSGal6STdeficient (KSGal6ST ${ }^{-l-}$ ) mice was as previously described ${ }^{35,36}$ Males of SOD $1{ }^{\mathrm{G} 93 \mathrm{~A}}$ hemizygotes were bred with GlcNAc6ST1 ${ }^{-/-}$or KSGal6ST ${ }^{-/-}$females. Generated $\mathrm{SOD}{ }^{\mathrm{G} 93 \mathrm{~A}} / \mathrm{GlcNAc} 6 \mathrm{ST} 1^{+/-}$or $\mathrm{SOD} 1^{\mathrm{G} 93 \mathrm{~A}} / \mathrm{KSGal}^{+1} \mathrm{ST}^{+/-}$ males were then bred with GlcNAc6ST1 ${ }^{+/}$or $\mathrm{KSGal6ST}^{+/-}$ females. The mice were kept under controlled environmental conditions and were provided with standard nourishment and water. All experimental procedures were approved by the Animal Research Committee of Nagoya University and conducted in accordance with the guidelines of Nagoya University.

\section{Colony Maintenance of the SOD1 ${ }^{\mathrm{G} 93 \mathrm{~A}}$ Transgenic Mice}

Colony maintenance and experimental tests for the SOD1 $1^{\mathrm{G} 93 \mathrm{~A}}$ transgenic mice and the transgenic progeny were performed in accordance with guidelines provided by The Jackson Laboratory. The SOD1 ${ }^{\mathrm{G} 93 \mathrm{~A}}$ transgene was genotyped with the genomic DNA isolated from a $0.5-\mathrm{cm}$ section of the tail. Isolation of tail DNA was performed by a sodium hydroxide extraction method. The tail section cut into small pieces was mixed with $180 \mu \mathrm{L}$ of $100 \mathrm{mmol} / \mathrm{L} \mathrm{NaOH}$. The sample was incubated at $95^{\circ} \mathrm{C}$ for 10 minutes, cooled to room temperature, and then neutralized with $20 \mu \mathrm{L}$ of $1 \mathrm{~mol} / \mathrm{L}$ Tris- $\mathrm{HCl}(\mathrm{pH} 8.0)$. The sample was centrifuged at $15,000 \times g$ for 10 minutes at $4{ }^{\circ} \mathrm{C}$. The supernatant fluid was subjected to PCR reactions. A total of $25 \mu \mathrm{L}$ of the PCR mixture contained $0.25 \mu \mathrm{L}$ of the tail DNA, $12.5 \mu \mathrm{L}$ of $2 \times$ PCR buffer for KOD FX, $0.4 \mathrm{mmol} / \mathrm{L}$ of each dNTP, $5 \mu \mathrm{mol} / \mathrm{L}$ of each primer, $2.5 \%(\mathrm{v} / \mathrm{v})$ dimethyl sulfoxide, and 0.5 units of KOD FX DNA polymerase (Toyobo, Osaka, Japan). The thermal cycling was set as follows: $94^{\circ} \mathrm{C}$ for 1.5 minutes, followed by 35 cycles of $94^{\circ} \mathrm{C}$ for 30 seconds, $60^{\circ} \mathrm{C}$ for 30 seconds, and $72^{\circ} \mathrm{C}$ for 30 seconds, and then $4^{\circ} \mathrm{C}$ until the samples were subjected to $1.5 \%$ agarose gel electrophoresis. The primers for the transgene (mutated SOD1) were 5'-CATCAGCCCTAATCCATCTGA-3' (forward) and $5^{\prime}$-CGCGACTAACAATCAAAGTGA-3' (reverse). ${ }^{37}$ Copy numbers of the transgene were determined with the use of realtime quantitative PCR (qPCR) in accordance with The Jackson Laboratory protocol run on Light Cycler 480 (Roche Diagnostics, Mannheim, Germany). The transgene copy number was determined by comparing the $\Delta \mathrm{Ct}$ value of each sample against a standard high-copy control and a low-copy control, with the use of appropriate endogenous references. All primers 
described in The Jackson Laboratory protocol were obtained from MBL (Nagoya, Japan). High-copy number transgenic mice were subjected to experimental analyses. Low-copy number transgenic mice were euthanized.

\section{Antibodies and Enzymes}

The following materials were obtained from the commercial sources indicated. 5D4 anti-KS monoclonal antibody was from Seikagaku (Tokyo, Japan); rabbit anti-GlcNAc6ST-1/ CHST2 antibody was from Sigma-Aldrich (St. Louis, MO); mouse anti-KSGa16ST/CHST1 antibody (clone A-2) was from Santa Cruz Biotechnologies (Dallas, TX); biotinylated rat antimouse Mac-2 was from Cedarlane (Burlington, NC); rabbit anti-Iba I antibody was from Wako (Osaka, Japan); horseradish peroxidase (HRP)-conjugated goat anti-mouse IgG1 was from Caltag (Burlingame, CA); HRP-conjugated goat anti-mouse $\operatorname{IgG} 2 \mathrm{~b}$, cyanine 2 (Cy2)-conjugated streptavidin, Cy3-conjugated goat anti-mouse IgG1, and Alexa Fluor 488conjugated goat anti-rabbit IgG $(\mathrm{H}+\mathrm{L})$ were from Jackson ImmunoResearch (West Grove, PA); and HRP-conjugated goat anti-rabbit $\operatorname{IgG}(\mathrm{H}+\mathrm{L})$ was from Cell Signaling Technology (Danvers, MA). Enzymes used for digestion were a2-3,6,8 neuraminidase (Arthrobacter ureafaciens) from Nacalai Tesque (Kyoto, Japan); $\alpha 1-3,4$-fucosidase (Streptomyces sp.) from Takara Bio Inc. (Shiga, Japan); keratanase II (Bacillus sp.) from Seikagaku; peptide-N-glycosidase F (PNGase F; Flavobacterium meningosepticum) from Roche Diagnostics (Indianapolis, Indiana); and $\alpha 1-2$ fucosidase (Xanthomonas manihotis), recombinant $\alpha$ - $N$-acetylgalactosaminidase, and $\alpha 1-3,6$ galactosidase (Xanthomonas manihotis) from New England Biolabs (Ipswich, MA).

\section{Human Postmortem Spinal Cord Tissues}

Patients with sporadic ALS received a pathologic diagnosis according to the El Escorial Diagnostic World Federation of Neurology criteria (Table 1). The diagnosis of ALS was histopathologically confirmed by the presence of intraneuronal Bunina bodies. Specimens of cervical (C3 to C6 segments) and lumbar spinal cords (L4 to L5 segments) from ALS cases and disease control cases were obtained. These specimens were frozen and then stored at $-80^{\circ} \mathrm{C}$. The collection of tissues, their use in this study, and the consent procedure were approved by the Ethics Committee of Nagoya University Graduate School of Medicine. The written informed consent was obtained from the patients' next-of-kin. Among the specimens examined, those with preserved expression of $\beta$-actin were subjected to evaluation of KS expression. Frozen spinal cords were homogenized with a Dounce tissue grinder in Tris-buffered saline (TBS; $20 \mathrm{mmol} / \mathrm{L}$ Tris and $137 \mathrm{mmol} / \mathrm{L} \mathrm{NaCl}, \mathrm{pH}$ 7.6) containing $1 \%$ Triton X-100 and protease inhibitors (complete protease inhibitor cocktail; Roche Diagnostics) and then used for biochemical analyses.
Table 1 Clinical Information of ALS Disease and Non-ALS Control Donor Patients Used in the Western Blot Analysis of the 5D4 Keratan Sulfate Epitope

\begin{tabular}{lllll}
\hline Patient number & $\begin{array}{l}\text { Age, } \\
\text { year }\end{array}$ & Sex & Disease & $\begin{array}{l}\text { ALS disease } \\
\text { duration, year }\end{array}$ \\
\hline ALS disease patients & & & & \\
ALS-230 & 61 & F & ALS & 5 \\
ALS-231 & 66 & M & ALS & 2.7 \\
ALS-233 & 53 & F & ALS & 2.7 \\
ALS-260 & 66 & M & ALS & 3 \\
Non-ALS controls & & & & \\
Ctrl-138 & 74 & F & MSA-P & \\
Ctrl177 & 77 & M & PSP & \\
Ctrl-216 & 84 & M & MG & \\
\hline
\end{tabular}

ALS, amyotrophic lateral sclerosis; F, female; M, male; MG, myasthenia gravis; MSA-P, multiple system atrophy with predominant parkinsonism; PSP, progressive supranuclear palsy.

\section{Mouse Tissues}

Mice were anesthetized and transcardially perfused with phosphate-buffered saline (PBS). Spinal cords and brains were dissected out and divided into cross-sectional segments and sagittal parts, respectively. Hemi-brains and segments of cervical, thoracic, and lumbar spinal cords were embedded in a compound for frozen sectioning. Thoracic and lumbar parts of spinal cords and regional parts of hemi-brains, namely, brainstem, thalamus, hippocampus, cerebellum, olfactory bulb, and the frontal motor region of cerebral cortex, were separated on ice, snap-frozen, and then stored at $-80^{\circ} \mathrm{C}$ for biochemical analysis.

\section{Isolation of Primary Microglia from Adult Mice}

Microglia were isolated from whole spinal cords of adult SOD1 ${ }^{\text {G93A }}$ and wild-type mice as previously described ${ }^{38}$ with minor modifications. SOD $1^{\mathrm{G} 93 \mathrm{~A}}$ littermate mice with end-stage disease were deeply anesthetized and perfused transcardially with ice-cold PBS. Spinal cords were dissected out, cut into fragments with a scalpel, and then incubated with an enzyme solution that contained $5 \mathrm{mg} / \mathrm{mL}$ collagenase and $10 \mu \mathrm{g} / \mu \mathrm{L}$ DNase I (Roche Diagnostics) for 45 minutes at $37^{\circ} \mathrm{C}$. The tissue was gently disrupted by pipetting several times with a $1-\mathrm{mL}$ pipette, filtered through a $70-\mu \mathrm{m}$ cell strainer, and then centrifuged at $190 \times g$ for 10 minutes. The cell pellet was suspended with myelin magnetic beads (Miltenyi Biotec, Bergisch Gladbach, Germany) to remove myelin debris. The cells were then pelleted and re-suspended with PBS supplemented with $0.5 \%$ bovine serum albumin (BSA), $2 \mathrm{mmol} /$ L EDTA, and CD11b magnetic beads (Miltenyi Biotec) for 15 minutes at $4^{\circ} \mathrm{C}$. The suspension was subjected to magnetic-activated cell sorting selection columns according to the manufacturer's instructions. CD11 $\mathrm{b}^{+}$cells were collected and suspended in Dulbecco's modified Eagle's/ F12 medium supplemented with $10 \%$ heat-inactivated fetal 
bovine serum. The cell suspension was seeded on a 6-well plate coated with poly-L-lysine (Sigma-Aldrich) and maintained in culture at $37^{\circ} \mathrm{C}$. The medium was replaced every 2 days. Collected $\mathrm{CD} 11 \mathrm{~b}^{+}$cells were characterized by qPCR, immunocytochemistry, and Western blot analysis. CD11 $\mathrm{b}^{-}$ cells in flow-through fractions on the mass spectrometry column were also collected and analyzed.

\section{Fractionation of Spinal Cord and Brain Samples}

Snap-frozen spinal cords and various regions of brains (approximately $20 \mathrm{mg}$ ) were taken in a $1.5-\mathrm{mL}$ tube and supplemented with $600 \mu \mathrm{L}$ (30 volumes of the tissue weight) of ice-cold TBS with protease inhibitors as previously described. ${ }^{39}$ The tube was then placed in the water bath of a Bioruptor sonicator (Cosmo Bio, Tokyo, Japan). Tissues were fragmented for 15 seconds with the maximum ultrasonic wave output four to five times until solid materials in the tube became invisible. The materials were then ultra-centrifuged at $100,000 \times g$ for 30 minutes at $4^{\circ} \mathrm{C}$. The supernatant fluid was collected and stored frozen as the TBS-soluble fraction. The resulting pellet was suspended in $600 \mu \mathrm{L}$ (the same volume) of TBS that contained $1 \%$ SDS, and the pellet was dissociated and centrifuged at $15,000 \times g$ for 20 minutes at room temperature. The resulting supernatant fluid was collected and stored frozen as the TBS-insoluble/1\% SDS-soluble fraction. The protein concentrations of both fractions were measured by the Bradford method.

\section{Enzymatic Treatment and Solvolysis}

Snap-frozen spinal cords were homogenized in TBS that contained 1\% Triton X-100 and protease inhibitors. Supernatant fluids were collected after centrifugation at $10,000 \times g$ for 30 minutes at $4{ }^{\circ} \mathrm{C}$. The protein concentration was measured by the Bradford method. For pretreatment, the samples were digested with $0.05 \mathrm{U} / \mathrm{mL}$ neuraminidase and/or $1 \mathrm{U} / \mathrm{mL} \alpha-1,3 /$ 4-L-fucosidase at $37^{\circ} \mathrm{C}$ for 2 hours. Then, the enzymatic reaction was stopped by heating the samples at $95^{\circ} \mathrm{C}$ for 5 minutes. The samples were then treated with $0.05 \mathrm{U} / \mathrm{mL}$ keratanase II at $37^{\circ} \mathrm{C}$ overnight. Digestion of the samples with $1 \mathrm{U} / \mathrm{mL}$ PNGase $\mathrm{F}$ or $\beta$-elimination (GlycoProfile $\beta$-elimination kit; Sigma-Aldrich), $\alpha 1-2$ fucosidase, recombinant $\alpha-N$-acetylgalactosaminidase, or $\alpha 1-3,6$ galactosidase was performed according to the manufacturer's instructions. Solvolysis was performed as described previously. ${ }^{40}$ Fourteen microliters (10 $\mu \mathrm{g}$ of protein) of each TBS-insoluble/1\% SDS-soluble fraction of SOD $1^{\mathrm{G} 93 \mathrm{~A}}$ spinal cord was dried in vacuo. A $14-\mu \mathrm{L}$ solution of $0.05 \mathrm{~N}$ methanolic $\mathrm{HCl}$ was prepared with the Methanolic $\mathrm{HCl}$ kit (Supelco Analytical, Bellefonte, PA) and then added to the dried materials. The materials were incubated at $4{ }^{\circ} \mathrm{C}$ to avoid influences of sialic acids within $\mathrm{KS}$ or at room temperature for 4 hours and then mixed with $1.4 \mu \mathrm{L}$ of $0.1 \mathrm{~N}$ $\mathrm{NaOH}$. The materials were dried in vacuo and then subjected to immunoblot analyses.

\section{Immunoblots}

The proteins $(20 \mu \mathrm{g})$ were separated with $7.5 \%$ polyacrylamide gel electrophoresis (SuperSep; Wako) and blotted onto a polyvinylidene difluoride membrane (GE Healthcare, Little Chalfont, United Kingdom). The membrane was blocked with 5\% skim milk in PBS that contained $0.1 \%$ Tween-20 for 1 hour at room temperature and then incubated at $4{ }^{\circ} \mathrm{C}$ overnight with primary antibody diluted in $5 \%$ skim milk in that contained $0.1 \%$ Tween-20. The next day, the membrane was washed several times with that contained $0.1 \%$ Tween-20 and incubated with HRP-conjugated secondary antibody at room temperature for 1 hour. Bound antibodies were visualized with chemiluminescent reagent Pierce Plus (Thermo Scientific) and autoradiography. Immunoblotting was performed with the following antibody concentrations: anti-KS 5D4 (dilution 1:1000), anti-GlcNAc6ST-1/CHST2 (dilution 1:1000), and anti-KSGal6ST/CHST1 (dilution 1:1000). Secondary antibodies were HRP-conjugated goat anti-mouse IgG1 (dilution 1:3000), goat anti-rabbit IgG $(\mathrm{H}+\mathrm{L})$ (dilution 1:1000), and goat anti-mouse IgG2b (dilution 1:5000), respectively. An anti- $\beta$-actin antibody (dilution $1: 10,000)$ was used as a loading control. The relative intensity of immunoreactive bands was quantified by calculating pixel densities of scanned images of the X-ray film. Densitometry analysis was performed in a blinded manner (T.F.) on a Macintosh computer with the use of the ImageJ version 1.44o (NIH, Bethesda, MD; http://imagej.nih.gov/ij). Levels of 5D4-KS, GlcNAc6ST1, and KSGal6ST were normalized to the levels of $\beta$-actin to control for protein loading.

\section{Immunohistochemistry}

Tissues were embedded in the Tissue-Tek O.C.T. compound (Sakura Finetek, Torrance, CA). Frozen tissues were cut into $10-\mu \mathrm{m}$ sections on a cryostat and collected on MAS-coated glass slides (SF17293; Matsunami, Osaka, Japan), fixed in ice-cold acetone for 15 minutes and then allowed to dry for 30 minutes. Sections were incubated with blocking solution (3\% BSA in PBS) for 15 minutes at room temperature, washed twice with PBS, and then incubated with a mixture of 5D4 (dilution 1:80) and biotinylated rat anti-mouse Mac-2 (dilution 1:200) or a mixture of 5D4 (dilution 1:80) and rabbit anti-Iba I antibody (dilution $1: 200)$ at $4^{\circ} \mathrm{C}$ overnight. The next day, after washing with PBS, the sections were incubated with a mixture of $\mathrm{Cy} 3$ conjugated goat anti-mouse IgG1 (dilution 1:250) and Cy2-conjugated streptavidin (dilution 1:250) or a mixture of Cy3-conjugated goat anti-mouse IgG1 and Alexa Fluor 488-conjugated goat anti-rabbit IgG $(\mathrm{H}+\mathrm{L})$ (dilution 1:250) for 60 minutes at room temperature, rinsed, and counterstained with Hoechst. Then, the sections were mounted with FluorSave (Merck, Darmstadt, Germany). Digital images were captured by fluorescence microscopy (model BX41 microscope; Olympus, Tokyo, Japan). Digital images at randomly selected five fields within the 
ventral horn area of three spinal cord sections (three mice for each genotype) and within the brainstem of three brain sections (three mice for each genotype) were captured in a blinded manner (K.U., T.F.). When a $\mathrm{Mac}^{+}$or an $\mathrm{Iba}^{+}$cell showed the 5D4-KS staining signals that surrounded the staining signal of Mac2 or Iba1, we categorized the cell as a $5 \mathrm{D} 4^{+} / \mathrm{Mac}^{+}$or $5 \mathrm{D} 4^{+} / \mathrm{Iba}^{+}$cell. Hoechst staining confirmed the cell body. The number of these stained cells was counted and quantitated. Immunostaining with an isotype-matched control (mouse $\operatorname{IgG1}$, biotinylated rat $\operatorname{IgG} 2 \mathrm{a}$, or rabbit $\operatorname{IgG}$ ) for each primary antibody gave no specific signals in the SOD $1^{\mathrm{G} 93 \mathrm{~A}}$ spinal cord or brainstem (data not shown).

\section{Immunocytochemistry}

BV-2 and N9 microglia cells were provided by Dr. Tony WyssCoray, Stanford University, Stanford, CA. The cells were transfected with pCMV6 Entry Myc/DDK-mChst1 and/or pCMV6-mChst2 as described previously. ${ }^{12}$ Forty-eight hours later, the cells were washed with PBS and then fixed with $4 \%$ paraformaldehyde in PBS for 15 minutes at room temperature. Sections were incubated with 3\% BSA in PBS for 30 minutes at room temperature for blocking and then incubated with 5D4 anti-KS antibody (dilution 1:500) overnight at $4^{\circ} \mathrm{C}$. Cells were washed three times with PBS, and bound antibody was detected with Cy3-anti-mouse IgG1 antibody (dilution 1:250). Images were captured with a fluorescence microscope.

\section{Immunoelectron Microscopy}

Mice were anesthetized with $50 \mathrm{mg}$ pentobarbital/kg (Dainippon Sumitomo Pharma, Osaka, Japan) and then transcardially perfused with PBS and 4\% paraformaldehyde/ $0.05 \%$ glutaraldehyde. Brains were dissected out, fixed overnight in $4 \%$ paraformaldehyde $/ 0.05 \%$ glutaraldehyde, and then sank sequentially in 10\%,15\%,20\%, and 30\% sucrose in PBS. Thirty-micron coronal brain sections were cut with a freezing microtome and then stored in a cryoprotective medium. Sections were blocked with PBS that contained 3\% BSA for 1 hour at room temperature. Sections were incubated with 5D4 (dilution 1:50) in PBS that contained 0.3\% BSA overnight at $4^{\circ} \mathrm{C}$. Sections were then incubated with $1.4 \mathrm{~nm}$ Nanogoldconjugated goat anti-mouse $\operatorname{IgG}(\mathrm{H}+\mathrm{L})$ (Nanoprobes, Yaphank, NY) overnight at $4{ }^{\circ} \mathrm{C}$. Sections were fixed again with $2 \%$ glutaraldehyde in $0.1 \mathrm{~mol} / \mathrm{L}$ phosphate buffer, followed by enlargement of the gold particles with the Gold Enhance EM Formulation (Nanoprobes). Sections were then postfixed with $2 \%$ osmium tetroxide in $0.1 \mathrm{~mol} / \mathrm{L}$ cacodylate buffer overnight at $4^{\circ} \mathrm{C}$. The specimens were examined in a JEM-1400 Plus transmission electron microscope (JEOL Ltd., Tokyo, Japan).

\section{qPCR}

Total RNA was extracted from frozen mouse tissues and primary microglia with the use of TRIzol Reagent (Invitrogen,
Carlsbad, CA) according to the manufacturer's instructions. Total RNA (5 to $7 \mu \mathrm{g}$ ) was subjected to reverse transcription in $100 \mu \mathrm{L}$ of buffer with random primers, using Superscript II Reverse Transcriptase (Invitrogen). Real-time quantitative PCR was performed on Mx3000P (Agilent Technologies, Santa Clara, CA) with the use of SYBR qPCR mix (Toyobo Co. Ltd., Osaka, Japan). PCR was performed with the following variables: $95^{\circ} \mathrm{C}$ for 10 seconds, 1 cycle and then 40 cycles of $95^{\circ} \mathrm{C}$ for 5 seconds and $60^{\circ} \mathrm{C}$ for 30 seconds. The relative expression levels of each mRNA were calculated with the $\Delta \Delta \mathrm{Ct}$ method, normalizing to the level of Gapdh. Conclusions were drawn from triplicate PCR reactions. The primer sequences used in this study are newly designed and were confirmed by using samples of mouse peripheral lymph nodes. ${ }^{41}$ The primers are as follows: for GlcNAc6ST1, 5'-GTATGGCCAAGACGCTGCAA-3' (forward) and 5'-AGATCCTCGTACCTCACCACCAAG-3' (reverse); for GlcNAc6 ST2, 5'-TCAAGTTCAAGGCGTGTCTGGTA-3' (forward) and 5'-CCGTTCCACAGGTCAGCATC-3' (reverse); for Glc NAc6ST3, 5'-TGGTGCGCTACGAGGATCTG-3' (forward) and $5^{\prime}$-TGTGGATCCAAGTCTGGAGCTG-3' (reverse); for GlcNAc6ST4, 5'-AGTATTGCAAGTTCACGCTGCTC-3' (forward) and $5^{\prime}$-CTCGCTGTGGCTGTCCAGTA-3' (reverse); for C6ST1, 5'-TGTTCCTGGCATTTGTGGTCATA- $3^{\prime}$ (forward) and 5'-CCAACTCGCTCAGGGACAAGA-3' (reverse); for KSGal6ST, 5'-CTGACAGATACTGGCTTGGCAGA-3' (forward) and 5'-GACATCCATGTGCTGGTTGAAGA-3' (reverse); for $\beta 1,4$-galactosyltransferase 4 , $5^{\prime}$-ACCTGCTGGAACACCTGCATC-3' (forward) and $5^{\prime}$-GTTCAGGAGCTTGGCTCGGTTA-3' (reverse); for $\beta 1,3-\mathrm{N}$-acetylglucosaminyltransferase 7 ( $\beta 3 \mathrm{Gnt} 7), 5^{\prime}$-TCCCAGCCGTCATGTATGGTAA-3' (forward) and 5'-ATGGTGGAGTTGCCGAGCTAA-3' (reverse); for $\beta-1,3-\mathrm{N}$-acetylglucosaminyltransferase 2 ( $\beta 3 \mathrm{Gnt} 2), 5^{\prime}$-TCTGGTCTCAGTTGCAAAGTCCTAA- $3^{\prime}$ (forward) and $5^{\prime}$-GGCTACCTGCTCATGAAGGCTAA-3' (reverse); for Axl, 5'-GGAGGAGCCTGAGGACAAAGC-3' (forward) and 5'-TACAGCATCTTGAAGCCAGAGTAGG-3' (reverse); for insulin-like growth factor 1, 5'-CCTCTGGGATACGGCACTTA-3' (forward) and $5^{\prime}$-GAAGGTCTTGGTGGCATGTT-3' (reverse); for IL-1 $\beta, \quad 5^{\prime}$-CCTGCAGCTGGAGAGTGTGGAT-3' (forward) and $5^{\prime}$-TGTGCTCTGCTTGTGAGGTGCT-3' (reverse); for tumor necrosis factor- $\alpha, 5^{\prime}$-AGCCCACGTCGTAGCAAACCAC- $3^{\prime}$ (forward) and 5'-AGGTACAACCCATCGGCTGGCA- $3^{\prime}$ (reverse); and for transforming growth factor- $\beta$, $5^{\prime}$-TACGGCAGTGGCTGAACCAA- $3^{\prime}$ (forward) and 5'-CGGTTCATGTCATGGATGGTG-3' (reverse).

\section{Statistical Analysis}

All data are presented as means \pm SD unless otherwise noted. The values were analyzed by unpaired Student's $t$-test or oneway analysis of variance with Dunnett's test with Prism software version 6 (GraphPad Software, La Jolla, CA). $P<0.05$ was considered statistically significant. Differences in survival times were analyzed with Kaplan-Meier survival statistics 
A

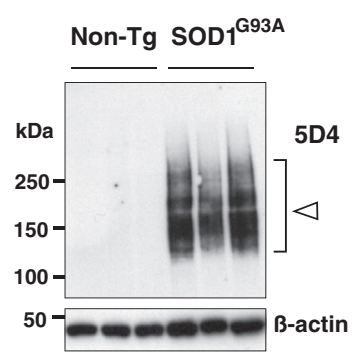

D

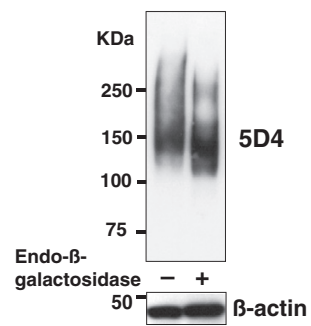

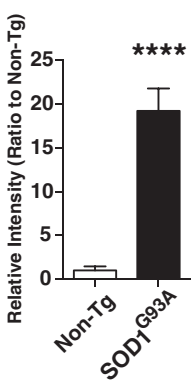

B

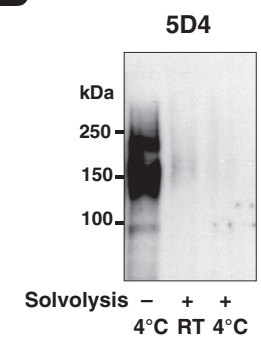

C

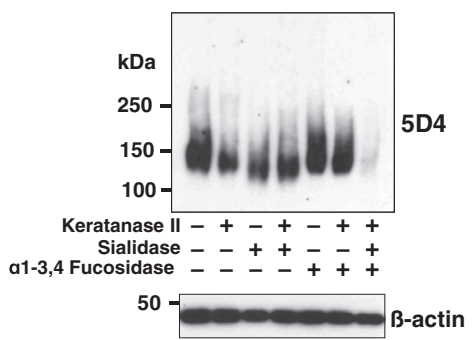

E

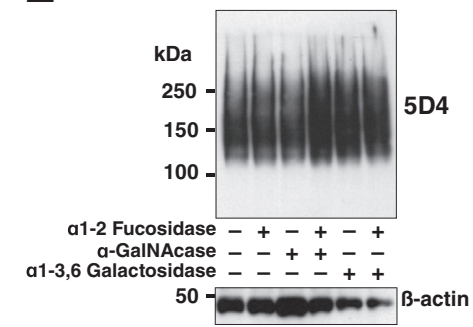

$\mathbf{F}$

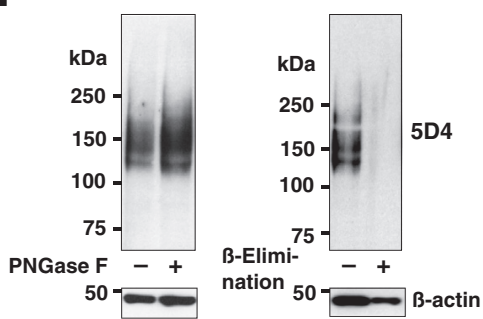

Figure 1 5D4-reactive keratan sulfate expressed in spinal cords of SOD1 ${ }^{\text {G93A }}$ mice consists of sialylated, fucosylated 0-glycans. A: TBS-insoluble/1\% SDS-soluble fractions were prepared from spinal cords of 24-week-old (disease end-stage) SOD1 ${ }^{\mathrm{G} 93 \mathrm{~A}}$ mice. Western blot analysis with $5 \mathrm{D} 4$ and quantitative analysis measuring the relative intensities of bands indicated by an open arrowhead were performed. B: Immunoreactivity of 5D4 on S0D $1^{\mathrm{G} 93 \mathrm{~A}}$ spinal cord homogenates after solvolytic desulfation reaction. C: One percent Triton X-100-soluble fractions of SOD ${ }^{\mathrm{G} 93 \mathrm{~A}}$ spinal cords were pretreated with $\alpha 2-3,6,8$ neuraminidase (sialidase), $\alpha 1-3,4$ fucosidase, or both at $37^{\circ} \mathrm{C}$ for 2 hours. Subsequently, the reaction mix was treated with keratanase-II at $37^{\circ} \mathrm{C}$ overnight. 0 ne percent Triton $\mathrm{X}-100-$ soluble fractions were pretreated with endo- $\beta$-galactosidase at $37^{\circ} \mathrm{C}$ for 2 hours (D) or with $\alpha 1-2$ fucosidase, GalNAcase, or $\alpha 1-3,6$ galactosidase (E). The treated samples were subjected to Western blot analysis with 5D4. F: One percent Triton X-100--soluble fractions of SOD1 ${ }^{\text {G93A }}$ spinal cords were incubated with PNGase F. TBS-insoluble/ $1 \%$ SDS-soluble fractions were subjected to $\beta$-elimination. The immunoreactivity of the $5 \mathrm{D} 4$ was tested. $n=3$ (non-Tg and S0D1 ${ }^{\mathrm{G} 93 \mathrm{~A}}$ mice). ${ }^{* * * * P}<0.0001$. GalNAcase, $\alpha-N$-acetylgalactosaminidase; PNGase F, peptide-N-glycosidase F; TBS, Tris-buffered saline; Tg, transgenic.

(log-rank test; SPSS Software version 23, IBM Japan, Tokyo, Japan).

\section{Results}

\section{Characterization of 5D4-Reactive KS}

In SOD1 ${ }^{\mathrm{G} 93 \mathrm{~A}}$ mice, significant death of motor neurons in the spinal cord occurs at the onset of clinical disease (at 12 weeks old). The mice show up to $50 \%$ loss of cervical and lumbar motor neurons by disease end stage (20 to 24 weeks old). ${ }^{32}$ To investigate the expression of the 5D4 KS epitope and sulfotransferase in the SOD1 ${ }^{\text {G93A }}$ ALS model mice in the end-stage and in their age-matched nontransgenic littermates, we performed Western blot analysis for spinal cord samples, which were fractionated as TBS-insoluble/1\% SDS-soluble. One band of high intensity corresponding to a size of 150 $\mathrm{kDa}$ and at least two bands of lower intensity with sizes of $200 \mathrm{kDa}$ and $250 \mathrm{kDa}$ were immunoreactive for 5D4 (Figure 1A). Quantitative analysis by measuring the intensities of these bands by densitometry revealed that there was a 22 -fold increase in the intensity of overall 5D4 recognition determinants in SOD1 ${ }^{\mathrm{G} 93 \mathrm{~A}}$ spinal cord extracts compared with that in the nontransgenic controls (Figure 1A). Desulfation of the SOD1 ${ }^{\mathrm{G} 93 \mathrm{~A}}$ lysate samples by solvolysis at room temperature and at $4{ }^{\circ} \mathrm{C}$ led to a substantial reduction in the 5D4 immunoreactivity (Figure 1B). We have reported that the treatment of keratanase II, an endo-type KS-degrading enzyme, diminished the 5D4 immunoreactivity in injured spinal cords. ${ }^{20}$ To determine whether the 5D4 epitope in the spinal cord of SOD $1^{\mathrm{G} 93 \mathrm{~A}}$ mice is susceptible to keratanase II, spinal cord lysates (1\% Triton X 100-soluble fractions) of 24week-old SOD1 ${ }^{\mathrm{G} 93 \mathrm{~A}}$ mice were treated with the enzyme. Unexpectedly, we observed that the 5D4 immunoreactivity remained after keratanase II treatment (Figure 1C). Certain classes of KS are modified with sialic acid and fucose. ${ }^{42,43} \mathrm{We}$ determined whether there are glycosylation modifications that could interfere with the keratanase II activity on the 5D4-reactive KS chains. We pretreated lysate samples of SOD1 ${ }^{\text {G93A }}$ spinal cords with $\alpha 2-3,6,8$ neuraminidase (sialidase), $\alpha 1-3,4$ fucosidase, or both, followed by keratanase II digestion. We found a mobility shift of the major $150 \mathrm{kDa}$ band in the case of the neuraminidase treatments. The major band was shifted to $130 \mathrm{kDa}$ (Figure 1C). Susceptibility of the $150-\mathrm{kDa}$ major band to keratanase II was not altered by $\alpha 2-3,6,8$ neuraminidase single pretreatment, as judged by almost the same level of 5D4 immunoreactivity remaining. $\alpha 1-3,4$ Fucosidase treatment showed mobility of the major band comparable with that on no treatment. Interestingly, the band became smeared (Figure 1C). When the lysate was pretreated with a mixture of the neuraminidase and the fucosidase, and subsequently treated with keratanase II, the 5D4 immunoreactivity was reduced to an undetectable level (Figure 1C). A comparable level of 5D4 immunoreactivity was 

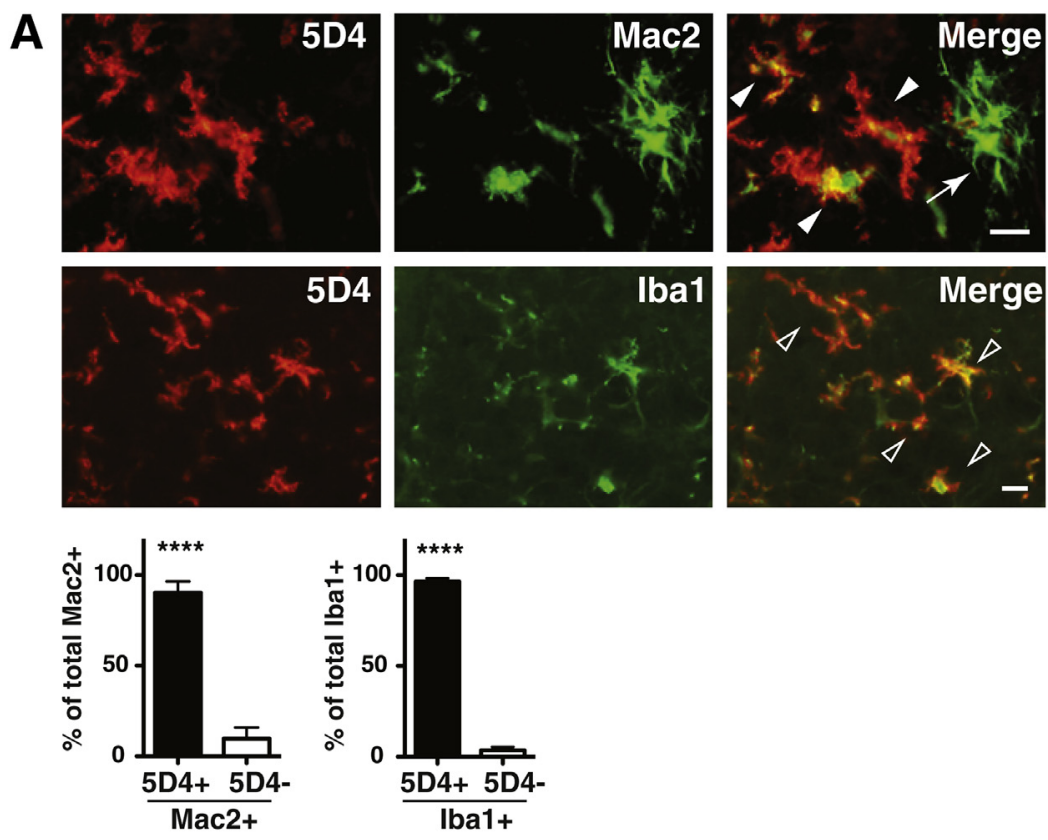

B

\section{CD11b+ primary cells}
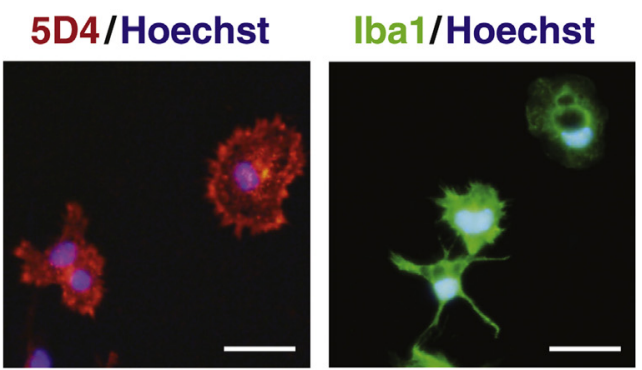

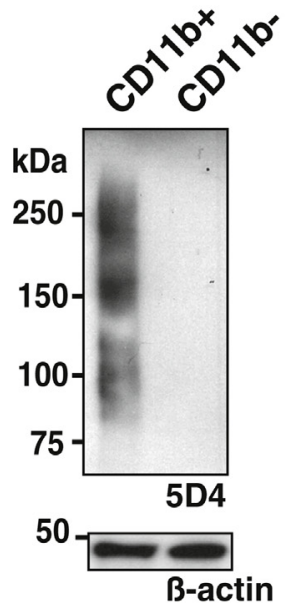

Figure 2 5D4-reactive keratan sulfate is expressed in $\mathrm{Mac}^{+}$microglia. A: Cryostat-cut spinal cord sections of 24week-old (disease end stage) SOD $1^{\mathrm{G} 93 \mathrm{~A}}$ mice were costained with 5D4 (red) and anti-Mac2 (green) or anti-Iba1 (green) antibody. Representative images of $5 \mathrm{D}^{+} \mathrm{Mac2}^{+}$ (arrowheads), 5D4 ${ }^{-} \mathrm{Mac2}^{+}$(arrow), and $5 \mathrm{D4}^{+} \mathrm{Iba1}^{+}$(open arrowheads) cells are shown. Graphs are of semiquantitative analysis of immunohistochemical images with Hoechst nuclear staining. Fractions of 5D4 ${ }^{+}$and $5 \mathrm{D}^{-}$cells among Mac2or Iba1-expressing cells were calculated as described in Materials and Methods. B: $\mathrm{CD}_{11} \mathrm{~b}^{+}$primary microglia isolated from SOD $1^{\mathrm{G} 93 \mathrm{~A}}$ spinal cords at the disease end stage were cultured for 4 days in vitro and stained with 5D4 (red) or Iba1 (green) antibody. Immunocytochemistry confirmed these isolated primary microglia to be $\mathrm{Iba}^{+}(98 \%)$ or $5 \mathrm{D} 4^{+}(90 \%)$. Representative images of fluorescently stained cells are shown. One percent Triton $X-100-$ soluble fractions were prepared and immunoblotted with 5D4. ${ }^{* * *} P<0.0001$. Scale bar $=25 \mu \mathrm{m}$. retained, but the major band slightly shifted to $140 \mathrm{kDa}$ on treatment with endo- $\beta$-galactosidase, another KS-degrading enzyme (Figure 1D). Treatment of the lysate with $\alpha 1-2$ fucosidase, $\alpha$ - $N$-acetylgalactosaminidase, or $\alpha 1-3,6$ galactosidase did not alter the 5D4 immunoreactivity (Figure 1E). Next, to determine whether the 5D4-reactive $\mathrm{KS}$ is linked through $N$ glycan or not, a $1 \%$ Triton X-100-soluble lysate of SOD1 ${ }^{\mathrm{G} 93 \mathrm{~A}}$ spinal cords was incubated with PNGase F and then subjected to Western blot analysis. The 5D4 immunoreactivity to the treated sample was comparable with that of the control sample (Figure 1F). $\beta$-Elimination reaction abolished the 5D4 immunoreactivity in the sample (Figure 1F).

\section{D4-Reactive KS Is Expressed in Mac2/Galectin3- Positive Microglia}

We previously showed that the 5D4 epitope is elicited in both $\mathrm{CD}_{86^{+}}$and $\mathrm{CD} 86^{-}$microglia in $\mathrm{SOD} 1^{\mathrm{G} 93 \mathrm{~A}}$ spinal cords at the disease end stage. ${ }^{34}$ To determine whether the 5D4 epitope is induced in activated and proliferating microglia, we stained SOD $1^{\mathrm{G} 93 \mathrm{~A}}$ spinal cord sections with an antibody against Mac2, a marker for activated and proliferating myeloid cells, including microglia. ${ }^{44} \mathrm{We}$ found that the Mac2 signals (90\%) and the signals of Iba1 (96\%), a microglia marker, were mostly colocalized with 5D4 signals (Figure 2A). Microglial expression of the 5D4-reactive KS was substantiated by signals seen in immunocytochemical staining and Western blot analysis in 4-day in vitro-cultured $\mathrm{CD} 11 \mathrm{~b}^{+}$primary microglia isolated from spinal cords of SOD1 ${ }^{\text {G93A }}$ end-stage mice (Figure $2 \mathrm{~B}$ ). CD11b magnetic bead-selected microglia from spinal cords were subjected to quantitative PCR analyses for genes of proinflammatory cytokines and neuroprotective factors for motor neurons. The level of mRNA expression of IL- $1 \beta$ significantly increased (11-fold) in SOD $1^{\mathrm{G} 93 \mathrm{~A}} / \mathrm{GlcNAc} 6 \mathrm{ST} 1^{-l-}$ primary microglia but not in $\mathrm{SOD}^{\mathrm{G} 93 \mathrm{~A}} / \mathrm{KSGal6ST}^{-/-}$microglia 
A

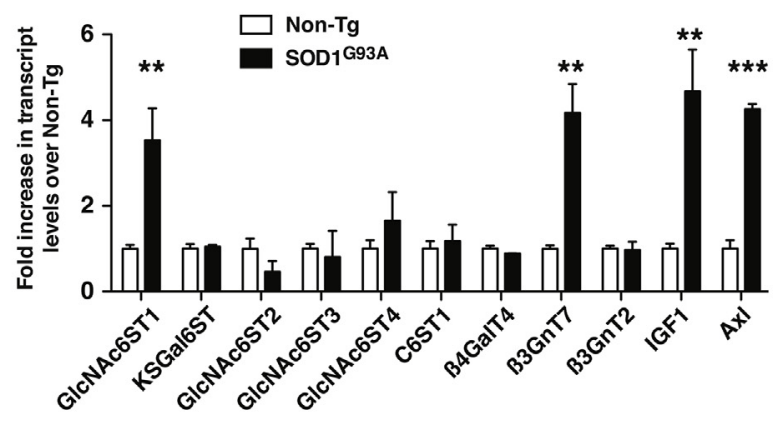

B
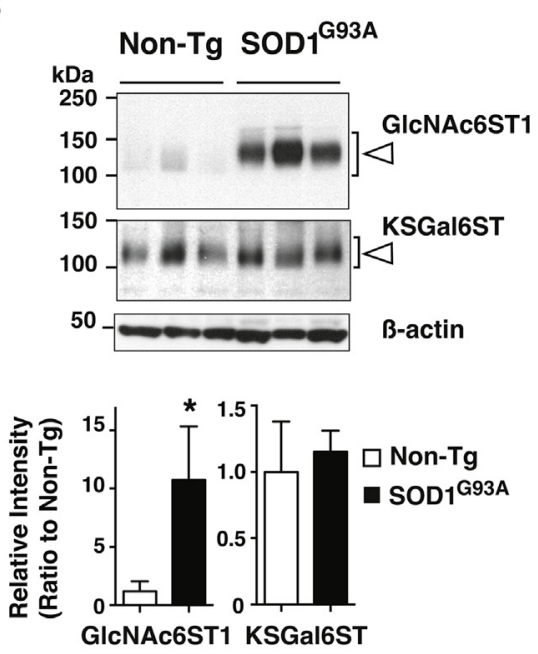

D

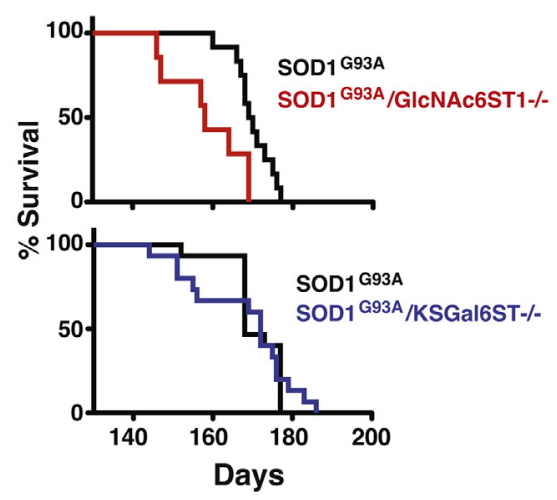

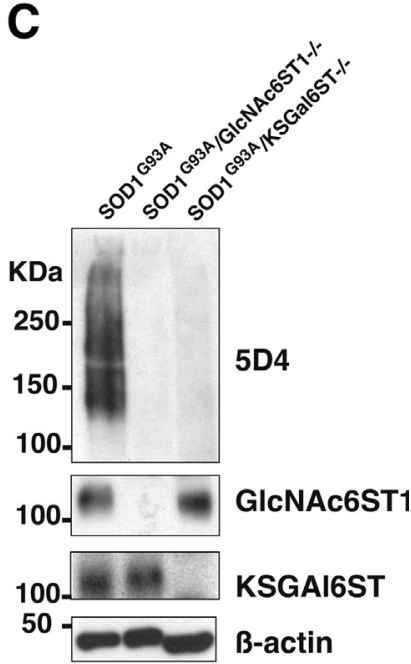

E
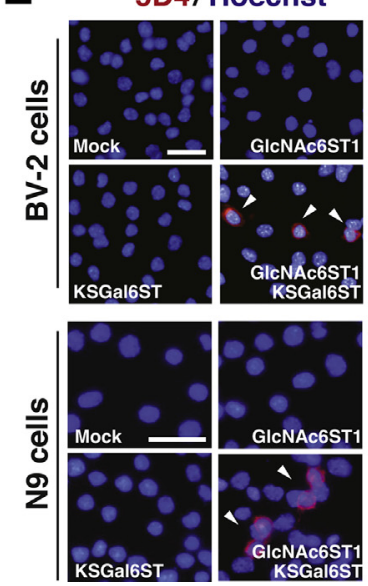

Figure 3 Sulfotransferases required for 5D4-reactive $\mathrm{KS}$ expressed in the spinal cord of SOD1 $1^{\mathrm{G} 93 \mathrm{~A}}$ mice. A: Total RNA from the spinal cords of 24-week-old non- $\mathrm{Tg}$ and $\mathrm{SOD}_{1}{ }^{\mathrm{G} 93 \mathrm{~A}}$ end-stage mice were prepared and tested. mRNA levels of Gal/GlcNAc/GalNAc sulfotransferases and KS glycosyltransferases were determined by quantitative real-time PCR. IGF1 and Axl were analyzed as described previously. ${ }^{37}$ B: TBS-insoluble/1\% SDS-soluble fractions were prepared from tissue homogenates of 24-week-old non- $\mathrm{Tg}$ and $\mathrm{SOD} 1^{\mathrm{G}}{ }^{\mathrm{G} 3 \mathrm{~A}}$ end-stage mice. Western blot analysis was performed with anti-GlcNAc6ST1 and anti-KSGal6ST antibodies. Relative intensities of bands indicated by open arrowheads were measured by densitometry as described in Materials and Methods. C: The spinal cord fractions were prepared from 24-week-old SOD $1^{\text {G93A, }}$ SOD $1^{\text {G93A }} / \mathrm{GlCNAC6ST}^{-/-}$, and $\mathrm{SOD} 1^{\mathrm{G} 93 \mathrm{~A}} /$ $\mathrm{KSGal6ST}^{-/-}$mice. Western blot analysis was performed. $\beta$-Actin was used as an internal loading control. D: Kaplan-Meier curve analysis shows a shortened median survival time of SOD ${ }^{693 \mathrm{~A}} / \mathrm{GlcNAc6ST}^{-1-}$ mice $(158 \pm 1.3$ days) compared with SOD1 ${ }^{\mathrm{G} 93 \mathrm{~A}}$ mice $(169 \pm 1.7$ days $)$ $(P=0.006$, log-rank test). Comparable median survival times of SOD1 ${ }^{\text {G93A }}$ mice $(168 \pm 5.1$ days $)$ and SOD1 ${ }^{\text {G93A }} /$ $\mathrm{KSGal6ST}^{-/-}$mice (172 \pm 1.9 days) are shown. All mice

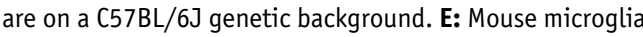
cells, BV-2 and N9, were transfected with CDNA of an empty vector (Mock), mouse GlcNAc6ST1, KSGal6ST, or both (GlcNAc6ST1/KSGal6ST). Cells were stained with 5D4 (red) and Hoechst (blue), and then visualized with a fluorescence microscope. Representative images of 5D4expressing cells (arrowheads) are shown. Data are expressed as medians \pm SE. $n=3$ (A and $\mathbf{B}$, non-Tg mice and SOD $1^{\mathrm{G} 93 \mathrm{~A}}$ end-stage mice); $n=7$ (D, SOD $1^{\mathrm{G} 93 \mathrm{~A}} /$ $\mathrm{GlcNAc6ST}^{-/-}$mice); $n=12$ (D, SOD1 ${ }^{\text {G93A }}$ mice); $n=15\left(\right.$ D, SOD ${ }^{\text {G93A }}$ and SOD $1^{\text {G93A }} / \mathrm{KSGal6ST}^{-/-}$mice $)$. ${ }^{*} P<0.05,{ }^{* *} P<0.01$, and ${ }^{* * *} P<0.001$. Scale bar $=$ $25 \mu \mathrm{m}$. Gal, galactose; GlcNAc, $N$-acetylglucosamine; GalNAc, N-acetylgalactosamine; IGF, insulin-like growth factor; KS, keratan sulfate; TBS, Tris-buffered saline; Tg, transgenic; KSGal6ST, keratan sulfate galactose-6sulfotransferase. compared with those from SOD1 ${ }^{\mathrm{G} 93 \mathrm{~A}}$ mice (Supplemental Figure S1). The level of mRNA expression of tumor necrosis factor- $\alpha$ significantly increased (1.5- to 2.0-fold) in both SOD $1^{\mathrm{G} 93 \mathrm{~A}} / \mathrm{GlcNAc} \mathrm{ST} 1^{-/-}$and $\mathrm{SOD} 1^{\mathrm{G} 93 \mathrm{~A}} / \mathrm{KSGal6ST}^{-/-}$ primary microglia. Interestingly, mRNA expression levels of transforming growth factor- $\beta$ (5.7-fold) and insulin-like growth factor 1 (1.9-fold) significantly increased in $\mathrm{SOD}^{\mathrm{G} 93 \mathrm{~A}} / \mathrm{KSGal6ST}^{-/-}$primary microglia (Supplemental Figure S1). Such up-regulation was not observed in SOD1 ${ }^{\mathrm{G} 93 \mathrm{~A}} / \mathrm{GlcNAc6ST}^{-l-}$ microglia.
Sulfotransferases Required for 5D4-Reactive KS in SOD1 ${ }^{\text {G93A }}$ Mice

To understand possible mechanisms of up-regulation of the 5D4 epitope in the spinal cord of the ALS model mouse, we measured the mRNA expression levels of six Gal/GlcNAc/ GalNAc sulfotransferases and three glycosyltransferases by qPCR. These are regarded as key enzymes in KS synthesis. The levels of mRNA expression of GlcNAc6ST1 and $\beta 3 \mathrm{GnT} 7$ significantly increased (3.5- to 4-fold) in 
A

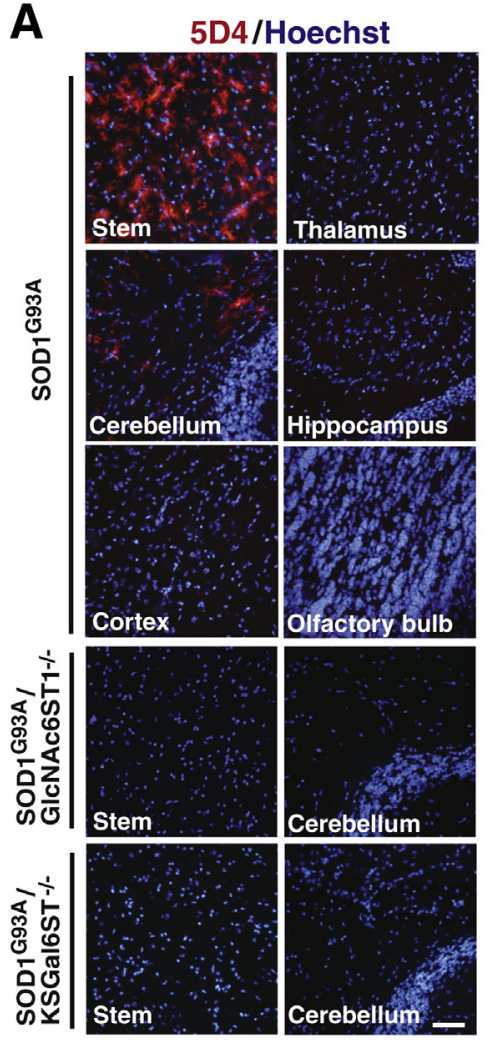

B
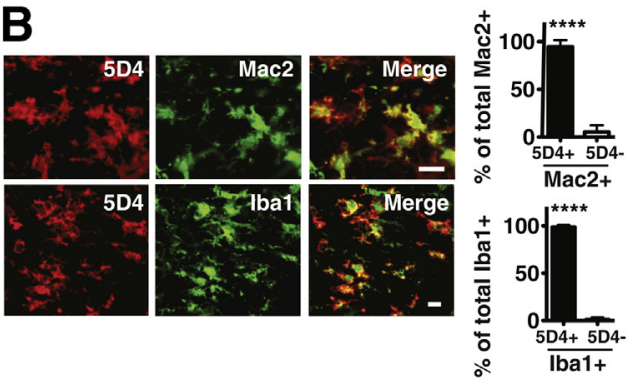

C

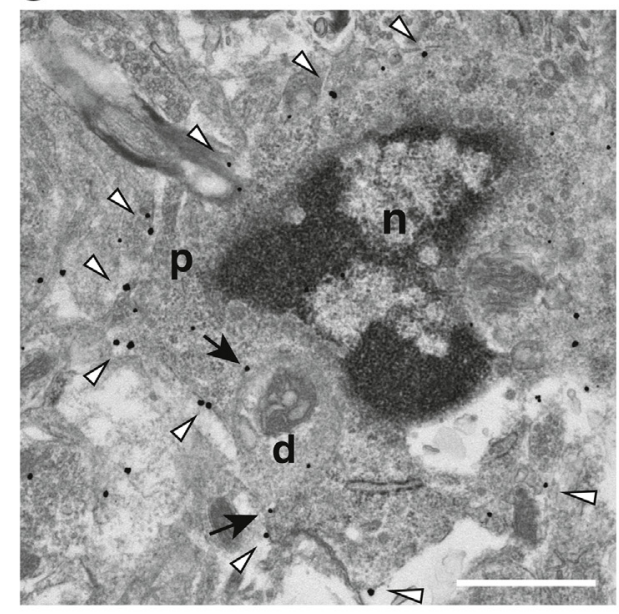

D

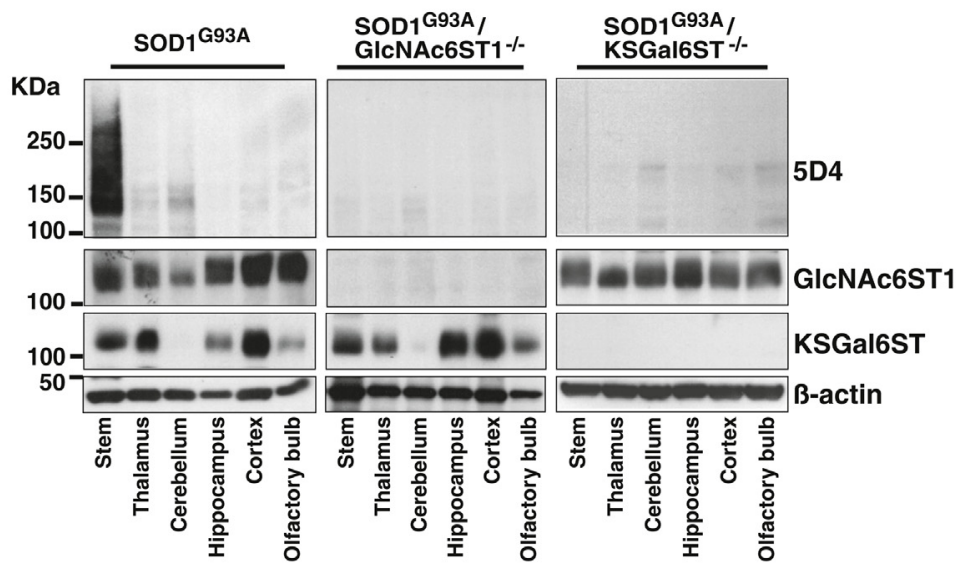

Figure 4 5D4-reactive $\mathrm{KS}$ is induced in the brainstem but not in the cerebral cortex of SOD $1^{693 A}$ mice. A: Brain specimens of SOD $1^{\mathrm{G} 93 \mathrm{~A}}$, SOD $1^{\mathrm{G} 93 \mathrm{~A}} /$ GlcNAc6ST1 ${ }^{-/-}$, and SOD $1^{\mathrm{G} 93 \mathrm{~A}} / \mathrm{KSGal6ST}^{-/-}$mice at the disease end stage were stained with 5D4 antibody (red). Nuclear staining was performed with Hoechst (blue). B: Cryostat-cut brainstem sections of 24week-old (disease end stage) SOD $1^{\text {G93A }}$ mice were co-stained with 5D4 (red) and anti-Mac2 (green) or anti-Iba1 (green) antibody. Graphs are of semiquantitative analysis of immunohistochemical images. Fractions of $5 \mathrm{D4}^{+}$and $5 \mathrm{D4}^{-}$cells among Mac2-or Iba1-expressing cells in the brainstem were calculated as described in Materials and Methods. C: Pre-embedding immunoelectron microscopy for the $5 \mathrm{D} 4$ epitope in the brainstem of the $\mathrm{SOD} 1^{\mathrm{GS}}{ }^{3 \mathrm{~A}}$ mouse at disease end stage. The nuclear membrane lined with dense heterochromatin is a distinguishing feature of microglia. 5D4 signals along with cell surface membrane structures of microglia and microglial processes are shown (open arrowheads). 5D4 signals found in membrane structures in microglial contacts with a dendrite are indicted (arrows). D: TBS-insoluble/1\% SDS-soluble fractions were prepared from brainstem, thalamus, cerebellum, cerebral cortex, hippocampus, and olfactory bulb of

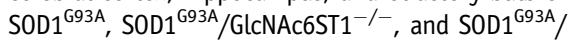
$\mathrm{KSGal6ST}^{-1-}$ mice. Western blot analysis was performed with $5 \mathrm{D} 4$ and antibodies against GlcNAc6ST1, KSGal6ST, and $\beta$-actin. ${ }^{* * * * P}<0.0001$. Scale bars: $45 \mu \mathrm{m}(\mathbf{A}), 25 \mu \mathrm{m}(\mathbf{B})$, and $1 \mu \mathrm{m}(\mathbf{C}) . d$, dendrite; $\mathrm{KS}$, keratan sulfate; $\mathrm{n}$, nucleus; $\mathrm{p}$, microglial perikaryon; KSGal6ST, keratan sulfate galactose-6sulfotransferase; GlcNAc, $N$-acetylglucosamine; TBS, Tris-buffered saline.
SOD1 ${ }^{\text {G93A }}$ spinal cords, whereas those of other sulfotransferases and glycosyltransferases were comparable with those of the nontransgenic controls (Figure 3A). Consistent with a report by Chiu et $\mathrm{al}^{45}$ that mRNA expression levels of insulin-like growth factor 1 and Axl receptor tyrosine kinase were up-regulated in $\mathrm{SOD} 1^{\mathrm{G} 93 \mathrm{~A}}$ spinal cords at the disease end stage, the levels of expression of these genes were increased 4.5-fold (Figure 3A). Immunoblotting was performed for TBS-insoluble/1\% SDS-soluble fractions of spinal cord samples with antiKSGal6ST and anti-GlcNAc6ST1 antibodies under nonreducing conditions. We found that the expression level of the GlcNAc6ST1 protein was increased 20-fold in SOD $1^{\mathrm{G} 93 \mathrm{~A}}$ mice, whereas that of KSGal6ST was comparable with the level of the nontransgenic mice (Figure 3B).
We then investigated whether the induced expression of 5D4-reactive KS could account for the expression of GlcNAc6ST1 and KSGal6ST in the SOD1 ${ }^{\text {G93A }}$ spinal cord. We generated $\mathrm{SOD} 1^{\mathrm{G} 93 \mathrm{~A}} / \mathrm{GlcNAc}_{\mathrm{STT}}{ }^{-1-}$ and $\mathrm{SOD} 1{ }^{\mathrm{G} 93 \mathrm{~A}} / \mathrm{KSGa} 6 \mathrm{ST}^{-/-}$mice. We corroborated that the disruption of GlcNAc6ST1 abolished the 5D4 epitope in the spinal cord (Figure 3C). Clearly, SOD ${ }^{\mathrm{G} 93 \mathrm{~A}}$ / $\mathrm{KSGal6ST}^{-1-}$ spinal cords did not show expression of the 5D4 epitope at the end stage (Figure 3C).

As we observed in the previous report, ${ }^{34}$ a life span of $\mathrm{SOD} 1{ }^{\mathrm{G} 93 \mathrm{~A}} / \mathrm{GlcNAc} \mathrm{ST} 1^{-1-}$ mice was significantly shortened compared with $\mathrm{SOD}_{1}{ }^{\mathrm{G} 93 \mathrm{~A}}$ mice (Figure 3D). SOD1 ${ }^{\mathrm{G} 93 \mathrm{~A}}$ / $\mathrm{KSGal6ST}^{-1-}$ mice showed a life span similar to that of $\mathrm{SOD}^{\mathrm{G} 93 \mathrm{~A}}$ mice (Figure 3D). We investigated whether GlcNAc6ST1 and KSGal6ST are sufficient to elaborate the 
5D4 epitope in mouse microglial cells. BV-2 and N9 cells were transfected with pcDNA3.1, pCMV6-Entry Myc/ DDK-mChst1, pCMV6-mChst2, or both pCMV6-Entry Myc/DDK-mChst1 and pCMV6-mChst2. ${ }^{12}$ The transfection efficiency was measured by counting the percentage of greenfluorescent cells in parallel experiments with pcDNA3-EGFP expression plasmid. The efficiency was determined to be $10 \%$ in BV-2 and N9 cells. Immunostaining by 5D4 showed that approximately $3 \%$ of BV-2 and N9 cells transfected with cDNAs for both GlcNAc6ST1 and KSGal6ST were positive for the stained signals (Figure 3E). Cells transfected with either cDNA alone did not show expression of the 5D4 epitope (Figure 3E).

\section{D4-Reactive KS Is Induced in the Brainstem but Not in the Cerebral Cortex of SOD $1^{\mathrm{G} 93 \mathrm{~A}}$ Mice}

Next, we investigated whether the 5D4-reactive KS might also be expressed in the brain of SOD $1^{\mathrm{G} 93 \mathrm{~A}}$ mice. Immunohistochemical analysis and Western blot analysis revealed that 5D4-reactive $\mathrm{KS}$ is abundantly expressed in the brainstem but not in the frontal motor cortex of SOD $1^{\mathrm{G} 93 \mathrm{~A}}$ mice at disease end stage (Figure $4, \mathrm{~A}, \mathrm{~B}$, and D). As seen in the spinal cord, 5D4 signals were mostly co-stained with the Mac2 signals (95\%) and the Ibal signals (99\%) (Figure 4B). A moderate level of the 5D4 signal was seen in the white matter of deep cerebellum nucleus (Figure 4, A and D). These prominent signals were not observed in either SOD $1^{\mathrm{G} 93 \mathrm{~A}} / \mathrm{GlcNAc} \mathrm{ST} 1^{-1-}$ or $\mathrm{SOD} 1^{\mathrm{G} 93 \mathrm{~A}} / \mathrm{KSGal} 6 \mathrm{ST}^{-/-}$ mice (Figure 4, A and D). We performed immunoelectron microscopy with 5D4. 5D4 ${ }^{+}$signals were seen in cell surface membrane structures of microglia and their processes (Figure 4C).

\section{Elicited 5D4-Reactive KS in Postmortem Spinal Cords of ALS Patients}

To test if the elicited expression of the 5D4 KS epitope in SOD $1^{\mathrm{G} 93 \mathrm{~A}}$ ALS model mice was also observed in ALS patients, we performed Western blot analysis for postmortem cervical and lumbar spinal cords of disease-control and sporadic ALS patients (Table 1), which were fractionated as $1 \%$ Triton X-100 soluble. All four ALS cervical spinal cords showed 5D4-immunoreactive smear bands with molecular weights of $>400 \mathrm{kDa}$ and $>250$ to $150 \mathrm{kDa}$. These bands were not detectable in all three disease control specimens (Figure 5). Two of the four ALS lumbar spinal cords showed 5D4-immunoreactive smear bands similar to those found in the cervical (Figure 5).

\section{Discussion}

In the present study, the structure of the 5D4-reactive KS was characterized. We found that the KS glycans expressed in the spinal cord of SOD1 $1^{\mathrm{G} 93 \mathrm{~A}}$ mice at the end stage are

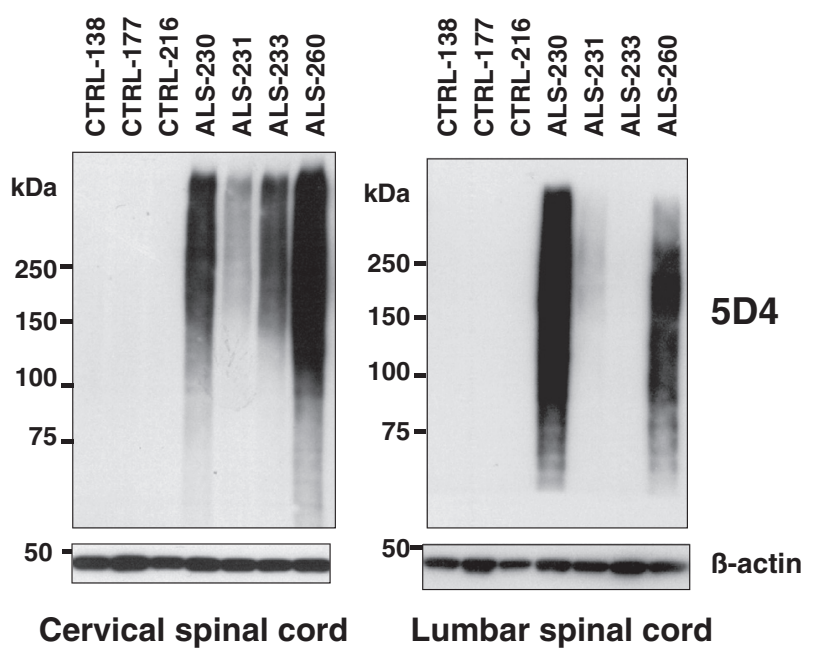

Figure 5 Expression of 5D4-reactive keratan sulfate up-regulated in spinal cords of ALS patients. One percent Triton X-100-soluble fractions were prepared from postmortem cervical and lumbar spinal cords of disease control and sporadic ALS patients. Proteins ( $20 \mu \mathrm{g} / \mathrm{lane})$ were loaded in each lane (Table 1). Western blot analysis with 5D4 and an anti- $\beta$-actin antibody was performed as described in Materials and Methods. $n=3$ (disease control); $n=4$ (ALS). ALS, amyotrophic lateral sclerosis.

produced as molecules of multiple sizes and that the 5D4 antibody does indeed recognize the sulfated moiety, as indicated by an apparent reduction in the 5D4 immunoreactivity after solvolysis. The 5D4-reactive KS expressed in the spinal cord of SOD $1^{\mathrm{G} 93 \mathrm{~A}}$ mice is resistant to keratanase II but becomes susceptible to it on pretreatment of the lysate sample with a neuraminidase and a fucosidase. It can be deduced that the presence of sialic acid and fucose residues within the 5D4-reactive KS glycans protects the KS against keratanase II by interfering with the endo-type cleavage. The poor susceptibility to endo- $\beta$-galactosidase well supports this prediction, as previously reported. ${ }^{46,47}$ These results indicate that 5D4-reactive $\mathrm{KS}$ is capped with sialic acids at its nonreducing terminus and composed of C6sulfated GlcNAc residues that are modified with $\alpha 3$-linked fucoses and that the 5D4-reactive KS is rather short, speculated to be composed of Sia $\alpha 2-3 \mathrm{Gal}(6 \mathrm{~S}) \beta 1-4 \mathrm{GlcNAc}(6 \mathrm{~S})$ $\beta 1-3 \mathrm{Gal} \beta 1-4(\alpha 1-3 \mathrm{Fuc}) \mathrm{GlcNAc}(6 \mathrm{~S}) \beta 1-6 \mathrm{R}$ or $-2 \mathrm{R}$ (the $\mathrm{R}$ denotes GalNAc or Man)

The absence of a clear change in the mobility and immunoreactivity of the 5D4-reactive bands on pretreatment with $\alpha 1-2$ fucosidase, $\alpha-N$-acetylgalactosaminidase, or $\alpha 1-3,6$ galactosidase suggested that the 5D4-reactive KS glycans are not modified with $\alpha 2$-linked fucose, nonreducing $\alpha$-GalNAc, or $\alpha 3$-linked Gal. The susceptibility to $\beta$-elimination but not PNGase $\mathrm{F}$ treatment indicated that the 5D4-reactive $\mathrm{KS}$ is elongated from an $O$-GalNAc or $O$-Man linkage. We concluded that sialylated and fucosylated KS, which was thus far reported in cartilage fibromodulin, ${ }^{43,48,49}$ is elicited in microglia with ALS pathogenesis.

GlcNAc6ST1 and KSGal6ST are responsible for the synthesis of KS in the early developing brain. ${ }^{12}$ We expected that the up-regulation of sulfotransferases is the cause of the 
induction of the $5 \mathrm{D} 4$ epitope of $\mathrm{KS}$ in $\mathrm{SOD} 1^{\mathrm{G} 93 \mathrm{~A}}$ mice. We found that both mRNA and protein levels of GlcNAc6ST1 are up-regulated in SOD $1{ }^{\mathrm{G} 93 \mathrm{~A}}$ spinal cords at the disease end stage, whereas the KSGal6ST levels are comparable with those of nontransgenic spinal cords. Up-regulation of GlcNAc6ST1 is consistent with the finding that Chst2 was identified as one of the 40 most differentially expressed genes in SOD $1^{\mathrm{G} 93 \mathrm{~A}}$ microglia. ${ }^{45}$ These results suggested that GlcNAc6ST1 might be a determinant of the expression of the $5 \mathrm{D} 4$ epitope in SOD1 ${ }^{\mathrm{G} 93 \mathrm{~A}}$ spinal cord in vivo. The genetic ablation of sulfotransferase in the spinal cord and brain, as shown in $\mathrm{SOD}^{\mathrm{G} 93 \mathrm{~A}} / \mathrm{GlcNAc} \mathrm{ST} 1^{-/-}$and $\mathrm{SOD} 1^{\mathrm{G} 93 \mathrm{~A}} /$ $\mathrm{KSGal6ST}^{-\prime-}$ mice, indicates that both GlcNAc6ST1 and KSGal6ST are required for the synthesis of the microglial 5D4 KS epitope elicited in SOD $1^{\mathrm{G} 93 \mathrm{~A}}$ spinal cord and brainstem. In accordance with this, our transfection experiments revealed that GlcNAc6ST1 and KSGal6ST cooperate in the synthesis of the 5D4 KS epitope in mouse microglia. Cerebral expression of the 5D4 epitope occurs selectively in the brainstem and the white matter of deep cerebellum nucleus, despite both GlcNAc6ST1 and KSGal6ST being expressed in regions of the SOD1 ${ }^{\mathrm{G} 93 \mathrm{~A}}$ brain tested. Although cells that express these sulfotransferases should be identified in the SOD $1^{\mathrm{G} 93 \mathrm{~A}}$ brain, a plausible explanation for the selective elicitation of the 5D4 epitope could be that there is an additional requirement for the expression of KS glycosyltransferases or core proteins that are potentially modified with the KS epitope in microglia. It was reported that elongation of the carbohydrate backbone of the KS chain is catalyzed by two glycosyltransferases, $\beta 3 \mathrm{GnT7}$ and $\beta 1,4-$ galactosyltransferase $4 .^{50-52}$ In addition to these enzymes, $\beta 3 \mathrm{GnT} 2$ is proposed to be responsible for KS chain elongation. ${ }^{52} \mathrm{We}$ found that mRNA of $\beta 3 \mathrm{GnT} 7$ is up-regulated in the $\mathrm{SOD} 1^{\mathrm{G} 93 \mathrm{~A}}$ spinal cord. It is conceivable that $\beta 3 \mathrm{GnT7}$ is another enzyme required for 5D4-reactive KS synthesis in microglia. This is consistent with the fact that co-transfection of cDNA of $\beta 3 \mathrm{GnT} 7$ enhanced generation of the 5D4 epitope in BV-2 and N9 mouse microglia (data not shown). Additional studies will be needed to determine the mechanisms underlying the up-regulation of GlcNAc6ST1 in the ALS model SOD $1^{\mathrm{G} 93 \mathrm{~A}}$ mice.

Efficient central nervous system delivery of neuroprotective factors for motor neurons was shown to extend life span in SOD1 ${ }^{\mathrm{G} 93 \mathrm{~A}}$ mice. ${ }^{53}$ Insulin-like growth factor 1 and transforming growth factor- $\beta$ levels were significantly higher in primary microglia isolated from the $\mathrm{SOD} 1^{\mathrm{G} 93 \mathrm{~A}}$ / $\mathrm{KSGal6ST}^{-1-}$ spinal cord. Such up-regulation was not seen in primary microglia isolated from $\mathrm{SOD} 1^{\mathrm{G} 93 \mathrm{~A}}$ / GlcNAc6ST $1^{-I-}$ mice. These factors may explain, in part, the differences in life span between SOD $1^{\mathrm{G} 93 \mathrm{~A}}$ / GlcNAc6ST1 ${ }^{-l-}$ and SOD ${ }^{\mathrm{G} 93 \mathrm{~A}} / \mathrm{KSGal6ST}^{-1-}$ mice, despite the elimination of microglial 5D4-KS being detected in both mice. Identification of the molecules bearing the 5D4 epitope in microglia would address these issues and help gain more insight into functional roles of $\mathrm{KS}$ in microglia.
Mac2 immunoreactivity is detected in activated and proliferating microglia associated with chronic or acute neuronal deficits, but absent in quiescent microglia. ${ }^{54}$ The 5D4-reactive $\mathrm{KS}$ is expressed in $\mathrm{Mac}^{+}$microglia in the $\mathrm{SOD} 1^{\mathrm{G} 93 \mathrm{~A}}$ spinal cord and brainstem. In the spinal cord and brainstem, lower motor neurons and upper motor neuronal tracts are present. Several studies have indicated that the neuropathology in SOD $1^{\mathrm{G} 93 \mathrm{~A}}$ mouse is confined largely to the degeneration of spinal and bulbar lower motor neurons but not in corticospinal upper motor neurons. ${ }^{55-57}$ The 5D4-KS was not detected in the SOD1 ${ }^{\mathrm{G} 93 \mathrm{~A}}$ cerebral cortex. In accordance with the results in SOD1 ${ }^{\mathrm{G} 93 \mathrm{~A}}$ mice, we found that expression of the 5D4-KS was apparently up-regulated in postmortem spinal cords of ALS patients. Thus, 5D4-KS expression is considered to occur in parallel to degeneration of the lower motor neurons in ALS.

Evidence has found that a subset of activated microglia have a potential role in neuronal functions by interacting with neurons and releasing neurotoxic or neurotrophic molecules and inflammatory cytokines. ${ }^{58}$ Our immunoelectron microscopy observations suggested that the 5D4-reactive KS might also be involved in microglial surveying and sensing the local environment by contacting other cells. 5D4 immunoreactivity could be useful to characterize a microglial state with activation in central nervous tissues.

Increasing evidence points to the involvement of the immune system in the pathogenesis of ALS ${ }^{59}$ The presence of T lymphocytes in the spinal cord of both ALS patients and ALS animal models was reported. ${ }^{60-62}$ The 5D4 epitope is expressed in a subpopulation of microglia that are CD86 ${ }^{+} .{ }^{34}$ It is assumed that a subset of the 5D4-expressing microglia may serve as proliferating antigen-presenting cells that regulate a neurodegeneration-induced inflammatory environment in the SOD $1^{\mathrm{G} 93 \mathrm{~A}}$ spinal cord by providing costimulatory signals to infiltrating $\mathrm{T}$ lymphocytes. The 5D4-reactive KS expressed on the cell surface of activated/ proliferating microglia could coordinate this intercellular interaction. ${ }^{63} \mathrm{CD}^{+} \mathrm{T}$ lymphocytes infiltrate into the lumbar spinal cord before the symptomatic stage and are required for the induction of alternatively activated microglia, which augment a neuroprotective environment in the $\mathrm{SOD} 1^{\mathrm{G} 93 \mathrm{~A}}$ spinal cord. ${ }^{60,61}$ Another possible contribution of the sulfotransferase might be elaboration of selectin ligand mucins ${ }^{41}$ being involved in the extravasation of $\mathrm{T}$ lymphocytes into neurodegenerating spinal cord and their modulation of the microglial trophic and cytotoxic balance. A decreased level of IL-4 in the SOD $1^{\mathrm{G} 93 \mathrm{~A}} / \mathrm{GlcNAc}_{\mathrm{SST}} 1^{-1-}$ spinal cord at pre-symptomatic stages ${ }^{34}$ could perhaps be due to reduced levels of infiltrated $\mathrm{CD} 4^{+} \mathrm{T}$ lymphocytes. These possibilities should be addressed in future study.

\section{Acknowledgments}

We thank Steven Rosen (University of California San Francisco, San Francisco, CA) for providing KSGal6ST KO 
mice, Tony Wyss-Coray (Stanford University, Stanford, CA) for providing BV-2 and N9 cells, Toshihiko Katoh (Complex Carbohydrate Research Center, Athens, GA) for advice on the solvolysis, and Shiori Ohtake-Niimi (Nagoya University, Nagoya, Japan) for technical assistance.

\section{Supplemental Data}

Supplemental material for this article can be found at http://dx.doi.org/10.1016/j.ajpath.2015.07.016.

\section{References}

1. Meyer K, Linker A, Davidson EA, Weissmann B: The mucopolysaccharides of bovine cornea. J Biol Chem 1953, 205:611-616

2. Funderburgh JL: Keratan sulfate: structure, biosynthesis, and function. Glycobiology 2000, 10:951-958

3. Kleene R, Schachner M: Glycans and neural cell interactions. Nat Rev Neurosci 2004, 5:195-208

4. Funderburgh JL: Keratan sulfate biosynthesis. IUBMB Life 2002, 54: 187-194

5. Krusius T, Finne J, Margolis RK, Margolis RU: Identification of an O-glycosidic mannose-linked sialylated tetrasaccharide and keratan sulfate oligosaccharides in the chondroitin sulfate proteoglycan of brain. J Biol Chem 1986, 261:8237-8242

6. Uchimura K: Keratan sulfate: biosynthesis, structures, and biological functions. Methods Mol Biol 2015, 1229:389-400

7. Tai GH, Huckerby TN, Nieduszynski IA: Multiple non-reducing chain termini isolated from bovine corneal keratan sulfates. J Biol Chem 1996, 271:23535-23546

8. Tai GH, Nieduszynski IA, Fullwood NJ, Huckerby TN: Human corneal keratan sulfates. J Biol Chem 1997, 272:28227-28231

9. Uchimura K, Rosen SD: Sulfated L-selectin ligands as a therapeutic target in chronic inflammation. Trends Immunol 2006, 27:559-565

10. Akama TO, Nishida K, Nakayama J, Watanabe H, Ozaki K, Nakamura T, Dota A, Kawasaki S, Inoue Y, Maeda N, Yamamoto S, Fujiwara T, Thonar EJ, Shimomura Y, Kinoshita S, Tanigami A, Fukuda MN: Macular corneal dystrophy type I and type II are caused by distinct mutations in a new sulphotransferase gene. Nat Genet 2000, 26:237-241

11. Hayashida Y, Akama TO, Beecher N, Lewis P, Young RD, Meek KM, Kerr B, Hughes CE, Caterson B, Tanigami A, Nakayama J, Fukada MN, Tano Y, Nishida K, Quantock AJ: Matrix morphogenesis in cornea is mediated by the modification of keratan sulfate by GlcNAc 6-O-sulfotransferase. Proc Natl Acad Sci U S A 2006, 103:13333-13338

12. Hoshino H, Foyez $\mathrm{T}$, Ohtake-Niimi S, Takeda-Uchimura $\mathrm{Y}$, Michikawa M, Kadomatsu K, Uchimura K: KSGal6ST is essential for the 6-sulfation of galactose within keratan sulfate in early postnatal brain. J Histochem Cytochem 2014, 62:145-156

13. Caterson B, Christner JE, Baker JR: Identification of a monoclonal antibody that specifically recognizes corneal and skeletal keratan sulfate. Monoclonal antibodies to cartilage proteoglycan. J Biol Chem $1983,258: 8848-8854$

14. Andrews PW, Banting G, Damjanov I, Arnaud D, Avner P: Three monoclonal antibodies defining distinct differentiation antigens associated with different high molecular weight polypeptides on the surface of human embryonal carcinoma cells. Hybridoma 1984, 3: 347-361

15. Magro G, Perissinotto D, Schiappacassi M, Goletz S, Otto A, Muller EC, Bisceglia M, Brown G, Ellis T, Grasso S, Colombatti A, Perris R: Proteomic and postproteomic characterization of keratan sulfate-glycanated isoforms of thyroglobulin and transferrin uniquely elaborated by papillary thyroid carcinomas. Am J Pathol 2003, 163: 183-196

16. Kawabe K, Tateyama D, Toyoda H, Kawasaki N, Hashii N, Nakao H, Matsumoto S, Nonaka M, Matsumura H, Hirose Y, Morita A, Katayama M, Sakuma M, Kawasaki N, Furue MK, Kawasaki T: A novel antibody for human induced pluripotent stem cells and embryonic stem cells recognizes a type of keratan sulfate lacking oversulfated structures. Glycobiology 2013, 23:322-336

17. Mehmet H, Scudder P, Tang PW, Hounsell EF, Caterson B, Feizi T: The antigenic determinants recognized by three monoclonal antibodies to keratan sulphate involve sulphated hepta- or larger oligosaccharides of the poly(N-acetyllactosamine) series. Eur J Biochem 1986, 157:385-391

18. Zhang H, Muramatsu T, Murase A, Yuasa S, Uchimura K, Kadomatsu K: N-Acetylglucosamine 6-O-sulfotransferase-1 is required for brain keratan sulfate biosynthesis and glial scar formation after brain injury. Glycobiology 2006, 16:702-710

19. Jones LL, Tuszynski MH: Spinal cord injury elicits expression of keratan sulfate proteoglycans by macrophages, reactive microglia, and oligodendrocyte progenitors. J Neurosci 2002, 22: $4611-4624$

20. Imagama S, Sakamoto K, Tauchi R, Shinjo R, Ohgomori T, Ito Z, Zhang H, Nishida Y, Asami N, Takeshita S, Sugiura N, Watanabe H, Yamashita T, Ishiguro N, Matsuyama Y, Kadomatsu K: Keratan sulfate restricts neural plasticity after spinal cord injury. J Neurosci 2011, 31:17091-17102

21. Ito Z, Sakamoto K, Imagama S, Matsuyama Y, Zhang H, Hirano K, Ando K, Yamashita T, Ishiguro N, Kadomatsu K: N-acetylglucosamine 6-O-sulfotransferase-1-deficient mice show better functional recovery after spinal cord injury. J Neurosci 2010, 30:5937-5947

22. Meyer-Puttlitz B, Milev P, Junker E, Zimmer I, Margolis RU, Margolis RK: Chondroitin sulfate and chondroitin/keratan sulfate proteoglycans of nervous tissue: developmental changes of neurocan and phosphacan. J Neurochem 1995, 65:2327-2337

23. Miller B, Sheppard AM, Pearlman AL: Developmental expression of keratan sulfate-like immunoreactivity distinguishes thalamic nuclei and cortical domains. J Comp Neurol 1997, 380:533-552

24. Miao J, Vitek MP, Xu F, Previti ML, Davis J, Van Nostrand WE: Reducing cerebral microvascular amyloid-beta protein deposition diminishes regional neuroinflammation in vasculotropic mutant amyloid precursor protein transgenic mice. J Neurosci 2005, 25: 6271-6277

25. Fan R, DeFilippis K, Van Nostrand WE: Induction of complement proteins in a mouse model for cerebral microvascular A beta deposition. J Neuroinflammation 2007, 4:22

26. Vidal R, Barbeito AG, Miravalle L, Ghetti B: Cerebral amyloid angiopathy and parenchymal amyloid deposition in transgenic mice expressing the Danish mutant form of human BRI2. Brain Pathol 2009, 19:58-68

27. Zhang C, Shen JK, Lam TT, Zeng HY, Chiang SK, Yang F, Tso MO: Activation of microglia and chemokines in light-induced retinal degeneration. Mol Vis 2005, 11:887-895

28. Beghi E, Logroscino G, Chio A, Hardiman O, Mitchell D, Swingler R, Traynor BJ; EURLAS Consortium: The epidemiology of ALS and the role of population-based registries. Biochim Biophys Acta 2006, 1762:1150-1157

29. Majounie E, Renton AE, Mok K, Dopper EG, Waite A, Rollinson S, et al: Frequency of the C9orf72 hexanucleotide repeat expansion in patients with amyotrophic lateral sclerosis and frontotemporal dementia: a cross-sectional study. Lancet Neurol 2012, 11:323-330

30. Rosen DR: Mutations in $\mathrm{Cu} / \mathrm{Zn}$ superoxide dismutase gene are associated with familial amyotrophic lateral sclerosis. Nature 1993, 364:362

31. Boillee S, Vande Velde C, Cleveland DW: ALS: a disease of motor neurons and their nonneuronal neighbors. Neuron 2006, 52:39-59

32. Gurney ME, Pu H, Chiu AY, Dal Canto MC, Polchow CY, Alexander DD, et al: Motor neuron degeneration in mice that express 
a human $\mathrm{Cu}, \mathrm{Zn}$ superoxide dismutase mutation. Science 1994, 264: $1772-1775$

33. Bruijn LI, Miller TM, Cleveland DW: Unraveling the mechanisms involved in motor neuron degeneration in ALS. Annu Rev Neurosci 2004, 27:723-749

34. Hirano K, Ohgomori T, Kobayashi K, Tanaka F, Matsumoto T, Natori T, Matsuyama Y, Uchimura K, Sakamoto K, Takeuchi H, Hirakawa A, Suzumura A, Sobue G, Ishiguro N, Imagama S, Kadomatsu K: Ablation of keratan sulfate accelerates early phase pathogenesis of ALS. PLoS One 2013, 8:e66969

35. Uchimura K, Kadomatsu K, El-Fasakhany FM, Singer MS, Izawa M, Kannagi R, Takeda N, Rosen SD, Muramatsu T: N-acetylglucosamine 6-O-sulfotransferase-1 regulates expression of L-selectin ligands and lymphocyte homing. J Biol Chem 2004, 279:35001-35008

36. Patnode ML, Yu SY, Cheng CW, Ho MY, Tegesjo L, Sakuma K, Uchimura K, Khoo KH, Kannagi R, Rosen SD: KSGal6ST generates galactose-6-O-sulfate in high endothelial venules but does not contribute to L-selectin-dependent lymphocyte homing. Glycobiology $2013,23: 381-394$

37. Alexander GM, Erwin KL, Byers N, Deitch JS, Augelli BJ, Blankenhorn EP, Heiman-Patterson TD: Effect of transgene copy number on survival in the G93A SOD1 transgenic mouse model of ALS. Brain Res Mol Brain Res 2004, 130:7-15

38. Hickman SE, Allison EK, El Khoury J: Microglial dysfunction and defective beta-amyloid clearance pathways in aging Alzheimer's disease mice. J Neurosci 2008, 28:8354-8360

39. Hosono-Fukao T, Ohtake-Niimi S, Hoshino H, Britschgi $M$, Akatsu H, Hossain MM, Nishitsuji K, van Kuppevelt TH, Kimata K, Michikawa M, Wyss-Coray T, Uchimura K: Heparan sulfate subdomains that are degraded by Sulf accumulate in cerebral amyloid $\beta$ plaques of Alzheimer's disease: evidence from mouse models and patients. Am J Pathol 2012, 180:2056-2067

40. Sugita M, Dulaney JT, Moser HW: Structure and composition of sulfatides isolated from livers of patients with metachromatic leukodystrophy: galactosyl sulfatide and lactosyl sulfatide. J Lipid Res 1974, 15:227-233

41. Uchimura K, Gauguet JM, Singer MS, Tsay D, Kannagi R, Muramatsu T, von Andrian UH, Rosen SD: A major class of Lselectin ligands is eliminated in mice deficient in two sulfotransferases expressed in high endothelial venules. Nat Immunol 2005, 6:1105-1113

42. Brown GM, Huckerby TN, Abram BL, Nieduszynski IA: Characterization of a non-reducing terminal fragment from bovine articular cartilage keratan sulphates containing alpha(2-3)-linked sialic acid and alpha(1-3)-linked fucose. A sulphated variant of the VIM-2 epitope. Biochem J 1996, 319(Pt 1):137-141

43. Lauder RM, Huckerby TN, Nieduszynski IA: Lectin affinity chromatography of articular cartilage fibromodulin: some molecules have keratan sulphate chains exclusively capped by alpha(2-3)-linked sialic acid. Glycoconj J 2011, 28:453-461

44. Rotshenker S: The role of Galectin-3/MAC-2 in the activation of the innate-immune function of phagocytosis in microglia in injury and disease. J Mol Neurosci 2009, 39:99-103

45. Chiu IM, Morimoto ET, Goodarzi H, Liao JT, O'Keeffe S, Phatnani HP, Muratet M, Carroll MC, Levy S, Tavazoie S, Myers RM, Maniatis T: A neurodegeneration-specific gene-expression signature of acutely isolated microglia from an amyotrophic lateral sclerosis mouse model. Cell Rep 2013, 4:385-401

46. Kannagi R, Fukuda MN, Hakomori S: A new glycolipid antigen isolated from human erythrocyte membranes reacting with antibodies directed to globo-N-tetraosylceramide (globoside). J Biol Chem 1982, 257:4438-4442
47. Spooncer E, Fukuda M, Klock JC, Oates JE, Dell A: Isolation and characterization of polyfucosylated lactosaminoglycan from human granulocytes. J Biol Chem 1984, 259:4792-4801

48. Lauder RM, Huckerby TN, Nieduszynski IA, Plaas AH: Age-related changes in the structure of the keratan sulphate chains attached to fibromodulin isolated from articular cartilage. Biochem J 1998, 330(Pt 2):753-757

49. Huckerby TN, Lauder RM: Keratan sulfates from bovine tracheal cartilage structural studies of intact polymer chains using $\mathrm{H}$ and $13 \mathrm{C}$ NMR spectroscopy. Eur J Biochem 2000, 267:3360-3369

50. Kitayama K, Hayashida Y, Nishida K, Akama TO: Enzymes responsible for synthesis of corneal keratan sulfate glycosaminoglycans. J Biol Chem 2007, 282:30085-30096

51. Seko A, Dohmae N, Takio K, Yamashita K: Beta 1,4galactosyltransferase (beta 4GalT)-IV is specific for GlcNAc 6-Osulfate. Beta 4GalT-IV acts on keratan sulfate-related glycans and a precursor glycan of 6-sulfosialyl-Lewis X. J Biol Chem 2003, 278: 9150-9158

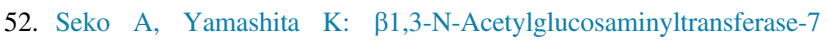
( $\beta 3 \mathrm{Gn}-\mathrm{T7})$ acts efficiently on keratan sulfate-related glycans. FEBS Lett 2004, 556:216-220

53. Kaspar BK, Llado J, Sherkat N, Rothstein JD, Gage FH: Retrograde viral delivery of IGF-1 prolongs survival in a mouse ALS model. Science 2003, 301:839-842

54. Lalancette-Hebert M, Gowing G, Simard A, Weng YC, Kriz J: Selective ablation of proliferating microglial cells exacerbates ischemic injury in the brain. J Neurosci 2007, 27:2596-2605

55. Leichsenring A, Linnartz B, Zhu XR, Lubbert H, Stichel CC: Ascending neuropathology in the CNS of a mutant SOD1 mouse model of amyotrophic lateral sclerosis. Brain Res 2006, 1096: $180-195$

56. Niessen HG, Angenstein F, Sander K, Kunz WS, Teuchert M, Ludolph AC, Heinze HJ, Scheich H, Vielhaber S: In vivo quantification of spinal and bulbar motor neuron degeneration in the G93A-SOD1 transgenic mouse model of ALS by T2 relaxation time and apparent diffusion coefficient. Exp Neurol 2006, 201:293-300

57. Ralph GS, Radcliffe PA, Day DM, Carthy JM, Leroux MA, Lee DC, Wong LF, Bilsland LG, Greensmith L, Kingsman SM, Mitrophanous KA, Mazarakis ND, Azzouz M: Silencing mutant SOD1 using RNAi protects against neurodegeneration and extends survival in an ALS model. Nat Med 2005, 11:429-433

58. Saijo K, Glass CK: Microglial cell origin and phenotypes in health and disease. Nat Rev Immunol 2011, 11:775-787

59. Henkel JS, Beers DR, Zhao W, Appel SH: Microglia in ALS: the good, the bad, and the resting. J Neuroimmune Pharmacol 2009, 4: 389-398

60. Beers DR, Henkel JS, Zhao W, Wang J, Appel SH: CD4+ T cells support glial neuroprotection, slow disease progression, and modify glial morphology in an animal model of inherited ALS. Proc Natl Acad Sci U S A 2008, 105:15558-15563

61. Beers DR, Zhao W, Liao B, Kano O, Wang J, Huang A, Appel SH, Henkel JS: Neuroinflammation modulates distinct regional and temporal clinical responses in ALS mice. Brain Behav Immun 2011, 25: $1025-1035$

62. Chiu IM, Chen A, Zheng Y, Kosaras B, Tsiftsoglou SA, Vartanian TK, Brown RH Jr, Carroll MC: T lymphocytes potentiate endogenous neuroprotective inflammation in a mouse model of ALS. Proc Natl Acad Sci U S A 2008, 105:17913-17918

63. Linnartz B, Bodea LG, Neumann H: Microglial carbohydratebinding receptors for neural repair. Cell Tissue Res 2012, 349: $215-227$ 